\title{
Origin of the southern Okinawa Trough volcanism from detailed seismic tomography
}

\author{
Jing-Yi Lin ${ }^{1,4, *}$, Jean-Claude Sibuet ${ }^{1}$, Chao-Shing Lee ${ }^{2}$, \\ Shu-Kun $\mathrm{Hsu}^{3}$ and Frauke Klingelhoefer ${ }^{1}$
}

\author{
${ }^{1}$ Ifremer, Centre de Brest, B.P. 70, 29280 Plouzané Cedex, France \\ ${ }^{2}$ Institute of Applied Geophysics, National Taiwan Ocean University, 2 Pei-Ning Road, Keelung 202, Taiwan \\ ${ }^{3}$ Institute of Geophysics, National Central University, Chung-Li 32001, Taiwan \\ ${ }^{4}$ now at Collège de France, Chaire de Géodynamique, Europôle de l'Arbois, Bat. Le Trocadéro - Aile Sud, BP 80, \\ 13545 Aix en Provence cedex 4, France \\ *: Corresponding author : lin@cdf.u-3mrs.fr
}

\begin{abstract}
:
Magmatism associated with subducting plate edges or slab tears has been suggested in the southern Okinawa Trough. The cross back-arc volcanic trail, which consists of a cluster of about 70 seamounts, is located above a Ryukyu slab tear lying along the $123.3^{\circ} \mathrm{E}$ meridian. In November 2003 , more than 3300 earthquakes recorded in this area by 15 ocean bottom seismometers and surrounding land stations during a period of 12 days were used to determine the three-dimensional $V p$ and $V s$ velocity structures and $V p / V s$ ratios. A mantle inflow characterized by low $V p$ and $V s$ and high $V p / V s$ passing through the slab tear is imaged. The fluid and/or melt component is rising obliquely from the slab tear in the directions of the cross back-arc volcanic trail, the northern slope of the southern Okinawa Trough and to north of Iriomote Island. The asthenospheric intake is also imaged by an inclined chiplike high $V p / V s$ and low $V p$ and $V s$ body dipping northerly, which might be linked to the slab retreat. West of the slab tear, most of the earthquakes are located around low $V p$ and $V s$ and high $V p / V s$ bodies, which suggests that the seismicity is related to magmatic and/or fluid activities. East of it, earthquakes are concentrated in an area characterized by high $V p$ and $V s$ velocities and low $V p / V s$, suggesting that the magma chamber is absent beneath the axial part of the trough and that normal faulting is the main factor controlling the seismicity.
\end{abstract}

Keywords: Southern Okinawa Trough back-arc basin; $V p / V s$ tomography; slab component volcanism 
Magmatism associated with subducting plate edges or slab tears has been suggested in the southern Okinawa Trough. The cross backarc volcanic trail, which consists of a cluster of about 70 seamounts, is located above a Ryukyu slab tear lying along the $123.3^{\circ} \mathrm{E}$ meridian. In November 2003, more than 3300 earthquakes recorded in this area by 15 ocean bottom

6 seismometers and surrounding land stations during a period of 12 days were used to 7 determine the three-dimensional $V p$ and $V s$ velocity structures and $V p / V s$ ratios. A mantle 8 inflow characterized by low $V p$, $V s$ and high $V p / V s$ passing through the slab tear is imaged.

9 The fluid and/or melt component is rising obliquely from the slab tear in the directions of the cross backarc volcanic trail, the northern slope of the southern Okinawa Trough and to north of Iriomote Island. The asthenospheric intake is also imaged by an inclined chip-like high $V p / V s$ and low $V p$, Vs body dipping northerly, which might be linked to the slab retreat. West of the slab tear, most of the earthquakes are located around low $V p$, $V s$ and high $V p / V s$ bodies, which suggests that the seismicity is related to magmatic and/or fluid activities. East of it, earthquakes are concentrated in an area characterized by high $V p$ and $V s$ velocities and low $V p / V s$, suggesting that the magma chamber is absent beneath the axial part of the trough and that normal faulting is the main factor controlling the seismicity.

\section{Introduction and Geological Setting}

The Okinawa Trough (OT), which extends from SW Kyushu to NE Taiwan, is widely regarded as an intra-continental backarc basin built behind the Ryukyu arc-trench system and linked to the northwestward subduction of the Philippine Sea $(\mathrm{PH})$ plate beneath the Eurasia

(EU) plate (Lee et al., 1980; Letouzey and Kimura, 1986; Sibuet et al., 1987) (Figure 1).

Seismic reflection data show that continental crust mostly underlies the entire Okinawa

24 Trough, with thickness varying from $\sim 18 \mathrm{~km}$ in the south to $\sim 30 \mathrm{~km}$ to the north (Hirata et al. 
1 1991; Sibuet et al. 1995). Based on detailed bathymetric data, Sibuet et al. (1998) have

2 identified three types of volcanism in the southern OT: the present-day backarc volcanism, the 3 present-day arc volcanism, and an abnormal “cross-backarc” volcanism. Extensional grabens 4 occurring in the OT are $\sim 10 \mathrm{~km}$ wide and 50 to $100 \mathrm{~km}$ long E-W overlapping features with 5 some elongated basaltic intrusions in the southwestern OT, which represent the first signs of 6 backarc activity (Sibuet et al., 1987). The present-day active volcanic front associated with 7 the Ryukyu subduction zone extends from Japan to the Ilan Plain (northern Taiwan). From 8 Kyushu to north of Okinawa Island, it follows a series of active volcanoes. Then the volcanic 9 front progressively migrates in the OT. In the southwestern OT, it is located 80-100 km above the Ryukyu slab (gray wide line in Figure 1) (Sibuet et al., 1998; Wang et al., 1999). It

terminates in the andesitic Kueishantao Island, $10 \mathrm{~km}$ offshore the Ilan Plain. The crossbackarc volcanic trail (CBVT), which consists of a cluster of about 70 seamounts located west of the $123^{\circ} \mathrm{E}$ meridian (Figures $1 \mathrm{a}$ and $1 \mathrm{~b}$ ), is considered as a voluminous anomalous volcanism emplaced within the backarc basin. Chung et al. (2000) suggested that these volcanoes are the products of arc magmatism. Shinjo (1999) emphasized that the southern OT is an "atypical" backarc basin as the generation of southern OT magmas involves a large subduction component compared with middle OT magmas.

Geodetic data proceeding from a compilation of GPS data (Imanishi et al., 1996; Yu et al., 1997), show that the Ryukyu Arc is presently moving southward with respect to Eurasia. This motion is presently occurring at a velocity of $4 \mathrm{~cm} / \mathrm{yr}$ along $\mathrm{N} 184^{\circ} \mathrm{E}$ azimuth (Lallemand and Liu, 1998), about $1.5 \mathrm{~cm} / \mathrm{yr}$ faster than in northern Taiwan (Ilan Plain) and in the east of the $123.3^{\circ} \mathrm{E}$ boundary (Iriomote Island). A recent investigation of the Ryukyu arc migration and backarc extension in the Okinawa Trough shows up to $5 \mathrm{~cm} / \mathrm{yr} \mathrm{N}-\mathrm{S}$ extension rates in the SW Okinawa Trough (Nishimura et al., 2004) and a higher slab rollback velocity in the southern Ryukyu arc area than estimated by Lallemand and Liu (1998). A three-dimensional flow 
1 pattern with two types of flow cells generated by subduction and rollback has been proposed

2 by Schellart (2004). The slab-dip parallel displacement produces two poloidal flow cells, one

3 in the mantle wedge above the slab and one underneath the subducting plate. The

4 displacement perpendicular to the slab (rollback) produces two toroidal-type flow cells, the

5 material initially located underneath the slab flowing around the lateral slab edges toward the

6 mantle wedge. An existence of a vertical tear in the slab would facilitate the lateral flow of

7 asthenospheric material around the slab edge. In addition, rollback-induced flows occur

8 around the lateral slab edges, forcing the hinge line to display a convex shape toward the

9 direction of retreat.

Crustal magmatic bodies are generally characterized by low $P$-wave $(V p)$, low $S$-wave (Vs)

velocity and high $P$-wave to $S$-wave $(V p / V s)$ ratios. Due to the sensitivity of $V p / V s$ to changes

in pore fluids (Ito et al., 1979; Mavko and Mukerji, 1995), this parameter is appropriate to image and detect fluids and thermal activity in volcanic systems (Koper et al., 1999;

Nakajima et al., 2001; Zhao et al., 2002). Based on tomographic results, an oblique fluid and/or melt pathway rising from the slab to the surface was imaged beneath northeastern Japan (Wyss et al., 2001). Beneath the western edge of the Ryukyu slab, a zone of low P- and $S$-wave velocities and high $V p / V s$ anomalies was observed in the vicinity of $121.8^{\circ} \mathrm{E}$ and interpreted as a feature enriched in $\mathrm{H}_{2} \mathrm{O}$ and/or melt corresponding to some asthenospheric flow conveyed around the edge of the slab (Lin et al., 2004b). In addition, a feeding channel starting from the slab border and bending in direction of the andesitic Kueishantao Island was imaged. Based on the inversion of magnetic data and the geochemistry of dredged rocks (Shinjo et al., 2003a and 2003b) in the CBVT area, a similar mechanism was proposed for the emplacement of the CVBT with a feeding origin coming from the slab tear located along the $123.3^{\circ} \mathrm{E}$ meridian (Lin et al., 2004a). The goal of this study is to image the crust and mantle 
1 the relationship between the different types of volcanism and the underlying slab and slab tear

2 as well as to understand the driving forces acting in this region. In this study, we will

3 determine the 3-D $P$ - and $S$ - wave velocities and the $V p / V s$ structure beneath the southern OT

4 by applying the SIMUL2000 method (Thurber and Eberhart-Phillips, 1999) with a minimal

5 spatial resolution of $15 \mathrm{~km}$ by using a large number of earthquakes recorded by 15 ocean

6 bottom seismometer (OBS) stations as well as by the surrounding land stations (Figure 2).

7

\section{Velocity Structures Beneath the Southwestern Okinawa Trough}

\section{1. Methodology and Data}

In November 2003, 15 OBSs of Geomar type (Auffret et al., 2004) were deployed in the southern OT (Figure 2). More than 3300 microearthquakes were recorded during this 12-days passive seismic experiment. Events recorded by land stations of the Central Weather Bureau (CWB) in Taiwan and the Japan Meteorological Agency (JMA) throughout the OBS recording period were also used in order to increase both the precision of the hypocenter determinations and the ray coverage. In total, 20 events of magnitude $>3$ were recorded simultaneously by the three networks (CWB, JMA and OBSs). The seismicity is mostly restricted to the central part of the southwestern OT, except for one cluster of events located in the southern part of it (cluster 2 in Figure 2). Most of the microearthquakes are aligned along E-W trending normal faults, showing that normal faulting is a major tectonic component in the axial part of the trough. The seismic activity terminates abruptly against the NE-SW trending Lishan fault extension suggesting that the Lishan fault extension is the present-day western boundary of the active OT and is a major crustal boundary (Lin et al., 2006, revised).

The tomographic inversion covers an area located between $23.5^{\circ}-26^{\circ} \mathrm{N}$ and $121.5^{\circ}-$ $124^{\circ} \mathrm{E}$ and a depth range of $0-100 \mathrm{~km}$ (Figures 3 and 4). The Velest program was used to get a minimum 1-D model (Kissling et al., 1994) that includes $P$ - and $S$ - wave velocities and station 
1 delays. This best-fit 1-D velocity model was used as the initial starting model for the

2 inversion. To obtain a better 3-D velocity model, only events located with an accuracy better

3 than $10 \mathrm{~km}$ in the three directions were selected, that is 2823 earthquakes. A total of 15,077

$4 \quad P$-wave and 13,751 $S$-wave arrival times recorded by the 15 OBSs and surrounding seismic

5 land stations were used in this study (Figure 3). After the relocation, the average rms residual

6 decreases from 0.242 to 0.151 second, showing a better determination of hypocenters. The

7 relocated earthquakes are offset by a mean value of about $2.4 \mathrm{~km}$ in the horizontal direction

8 and about $3.88 \mathrm{~km}$ in depth. Because $V p / V s$ ratio (Poisson's ratio) is the major parameter to

9 infer fluid or melt content and mechanical rock properties, the inversion for $V p / V s$ was

10 preferred to the direct ratios of 3-D $P$ - and $S$ - velocities. In fact, the 3-D $\mathrm{Vp} / \mathrm{Vs}$ structure is

11 hampered by the tendency for the $S$-velocity structures to be less resolved than the $P$-velocity

12 structures (Eberhart-Phillips, 1990; Thurber, 1993). Thus, instead of computing directly the

$V p / V s$ structure from $V p$ and $V s$ values, we used the $V p$ and $V s$ residual time arrivals to

calculate $V p / V s$ ratios. The SIMUL2000 program was applied to invert the $V p$ and $V p / V s$ structures (Thurber and Eberhart-Phillips, 1999).

Checkerboards (Zelt, 1998) or spikes (Spakman and Nolet, 1998) are common synthetic input models to assess the amount of image blurring in data sets. These tests usually involve the construction of synthetic input velocity models and the computation of synthetic travel times using the source receiver distribution of the real data set. In this study, we assigned positive and negative velocity perturbations of $\pm 3 \%$ alternatively to the grid nodes and calculated travel times to produce synthetic data. The synthetic data were then inverted with an initial model of zero velocity perturbation. As can be inferred from Figures $4 \mathrm{a}$ and $4 \mathrm{~b}$, the resolution of the central part of the southern OT is good at all depths except at 5 and $60 \mathrm{~km}$. The Ryukyu Arc is also well resolved when the grid spacing is large enough (Figure 4a). East of $123^{\circ} \mathrm{E}$, the checkboard distribution shows strongly decreasing amplitudes of the input 
1 anomalies but the checkerboard pattern is still discernible at shallow depth (10 to $30 \mathrm{~km}$ ). In

2 order to obtain a more detailed and reliable result, different gridding space intervals were

3 tested in function of the ray path density. A fine gridding interval (slave grid) was used in the

4 volumes of high ray path density in order to increase the fine scale resolution. In the regions

5 of poor checkerboard test resolution, values of the slave grids (gray circles) are identical to

6 values of the adjacent master grids (stars) (Figure 4). The linkage of slave and master grids

7 helps to recover a reliable smoothed structure in the volumes of low ray path distribution. The

8 minimal spacings for the master and slave nodes are 45 and $15 \mathrm{~km}$ respectively. Damping

9 values were set up at 10 for $V p$ and $V p / V s$ by analyzing trade-off curves between model variance and data variance (Eberhart-Phillips, 1986) (Figure 5). The chosen damping values

11 provide the largest reduction in data variance without strongly increasing model variance, hence yielding the smoothest solution to fit the data. Plotting the resolution estimates such as hit counts, diagonal elements of the resolution matrix (RDE) and spread function are common ways to assess the ray coverage (e.g. Reyners et al., 1999; Husen et al., 2000). In this study, the RDE values are used to show the resolution. The model resolvability increases as RDE approaches 1.0.

\section{2. Tomographic Inversion and Results}

$P$-, $S$ - wave and $V p / V s$ ratio perturbations are presented in Figures 6 to 8 for eight slices ranging from 5 to $60 \mathrm{~km}$. Tomographic results are displayed in percentage of variations with respect to the average value calculated at a given depth. The distribution of data resolution $\mathrm{RDE}$ is consistent with the checkboard test results. For example, RDE are relatively high ( $>0.6$ ) for the $V p$ data resolution in the central part of the southern OT at shallow depth (5 to $40 \mathrm{~km}$ ) (Figure 9). For the deeper part, the resolution decreases but is still acceptable beneath the Ryukyu Arc (>0.5). The $V p / V s$ data resolution (Figure 10) is very similar to the $V p$ data resolution. Checkerboard tests or spike sensitivity tests as described above cannot be used to 
assess the power of data to resolve a particular feature. The ability of the data to resolve a

2 fine-scale structure of the size of the checkerboard grid does not imply that large-scale

3 structures can be resolved as well (Levêque et al., 1993). Following Haslinger (1999) and

4 Husen et al. (2000), a synthetic input model, called the characteristic model was designed, and

5 based on the inverted results obtained with 'real' data. The characteristic Vp model displays

6 the resulting velocity anomalies at 15, 20, 30 and $50 \mathrm{~km}$ depth (Figure 11) corresponding to

7 the depth of the larger anomalies after inversion. The recovery of the input structure is

8 generally good, except at a depth of $50 \mathrm{~km}$, where the velocity anomalies in the northern part

9 of the southern OT are not well imaged (Figure 11).

In Figures 6 and 7, a WNW-ESE trending high $V p$ and $V s$ zone is observed beneath the Ryukyu Arc at depths of 50 and $60 \mathrm{~km}$. This trend corresponds to the $50 \mathrm{~km}$ isobath of the

12 Ryukyu slab determined by the distribution of epicenters (Font et al., 1999). On $V p / V s$ tomographic slices (Figure 8), several areas with $V p / V s$ higher than 1.78 are observed. Since the presence of melt or $\mathrm{H}_{2} \mathrm{O}$-enriched material is characterized by low $V p$, low $V s$ and high Vp/Vs (Watanabe, 1993; Miller and Smith, 1999; Reyners et al., 2006), such areas have been highlighted by white dashed contours (Figures 6 to 11). Several patches are observed and tend to be concentrated in the OT axial depression at shallow depth. According to their changing directions with depth, these anomalies were grouped into two series of channels as shown in Figure 12. For the first group (Figure 12a), the anomalous area starts in the mantle wedge beneath the northern slope of the southern OT and rises southerly from a depth larger than 30 $\mathrm{km}$ to the surface. Then, it extends west of $123^{\circ} \mathrm{E}$, at a depth of $10 \mathrm{~km}$, along a WNW-ESE direction between Yonaguni and Kueishantao Islands. This group of anomalies might extend northerly out of our target area, and cannot be tracked further north as the resolution becomes too poor at the edge of the grid. 
The root of the second group is located at $50 \mathrm{~km}$, beneath the uppermost part of the slab

2 (Fig. 12b). Then, it subdivides into three independent branches. A first branch rises northwesterly in direction of the CBVT, and connects to a body located at shallow depth, beneath the CBVT area. A second branch rises northeastward in direction of Iriomote Island. Compared to the main channel which arrives in the upper crust, this subchannel disappears at a depth of $30 \mathrm{~km}$, beneath Iriomote Island, demonstrating why the southwestern portion of the Ryukyu Arc is not volcanic. Although only a few earthquakes were identified in the OBS experiment, a cluster of earthquakes located by the JMA may be related to this anomaly at depth (Lin et al., 2006, revised). Numerous hot spring locations have been reported in the southern OT (Lee, 2005). Their locations correspond to the previous tomographic anomalies identified at shallow depths (10 to $30 \mathrm{~km}$; Figure 12), suggesting a magmatic correlation for the hot vents. The third branch rises northerly above the slab tear to a depth of $15 \mathrm{~km}$ beneath the northern slope of the southern OT.

Five $V p$, $V s$ and $V p / V s$ vertical profiles (located in Figures 12 and 13) have been extracted

(Figure 13). In Figure 13a, the $P$-wave tomographic velocities along Profile L1 are compared with the wide-angle reflection and refraction P-wave velocity model of Wang et al. (2002). The three black dashed lines show the 5.5, 6.75 and $7.75 \mathrm{~km} / \mathrm{s}$ contours. The two models are in good agreement in the area between the Ryukyu Arc and the southern OT central graben but our tomographic model does not properly show the location of the slab because the resolution of data is too poor (Figures 9 and 10). North of the southern OT, the model proposed by Wang et al. (2002) displays higher values than our model because raypaths are absent at the end of the seismic refraction profile. Figures 13b and 13c show the comparison between models obtained from different earthquake data sets by Nakamura et al. (2003) and in this study (Profile L3). The two profiles show similar trends for the Vp and Vs distributions but the model in our study shows a better resolution because the grid spacing is smaller and 
1 the density of earthquake distributions is higher in our study. High $V p$ and $V s$ values at

2 shallow depths (0 to $20 \mathrm{~km}$ ) and at a distance of $110 \mathrm{~km}$ and relatively low $V p$ and $V s$ values

3 at a depth of $50 \mathrm{~km}$ and at a distance of $60 \mathrm{~km}$ are observed in the two models. However, the

$4 \quad V p / V s$ distributions differ in the northern and southern parts of the profile. This difference

5 might be due to the poor resolution at the edge of grid for the two models. However, high

$6 \quad \mathrm{Vp} / \mathrm{Vs}$ anomalies located beneath the southern OT central graben and Ryukyu Arc are imaged

7 in the two tomographic models. In figures $13 \mathrm{~d}$ to $13 \mathrm{~h}$, the $V p, V s$ and $V p / V s$ values are

8 displayed in percentages of variations with respect to the average value calculated at a given

9 depth in order to better image the $P$ - and $S$ - variations of velocity anomalies. Profiles L3 is located west but close to the slab tear. A high $V p / V s$ body rises from the slab at a depth of 50 $\mathrm{km}$ in the direction of the southern OT central graben and then propagates along a $\mathrm{N}-\mathrm{S}$ direction at shallow depths (0 to $25 \mathrm{~km}$ ) (dashed red lines in Figures 13e and 13f). This anomaly corresponds to the third branch previously described. Profiles L1 and L2 are located in the area between Taiwan and the slab tear (inset in Figure 13). In Profile L1, a high $V p / V s$ body also characterized by low $V p$ and $V s$ is located at about $100 \mathrm{~km}$ north of the trench and $50 \mathrm{~km}$ above the slab (red dotted lines, Figure 13d) and rises parallel to the dip of the slab. A similar feature is also displayed in Profile L2 (red dotted lines in Figure 13e) which cuts across the CBVT area where the strongest high $V p / V s$ anomalies reache $6 \%$ ( 1.82). Profile L4 is also close to the slab tear but on its eastern side. Instead of a low $V p$, $V s$ and high $V p / V s$ distribution, this profile is characterized by high $V p$, Vs and low $V p / V s$ values (Figure 13g).

21 The wide extend of the low $V p / V s$ values along this profile implies the absence of partial melt and/or $\mathrm{H}_{2} \mathrm{O}$ enriched material in the lower crust and upper mantle, at least inside volumes larger than the spatial resolution of the inversion $(10 \mathrm{~km})$. This observation suggests that the high $V p / V s$ anomalies are mostly concentrated west of the slab tear. East of Profile L4, high Vp/Vs values are observed along Profile L5, but with a pattern which largely differs from the 
1 one observed along the other profiles. Only two small bodies of low $V p$, $V s$ and high $V p / V s$

2 anomalies are observed, one is located beneath the central graben at depth of 25 to $35 \mathrm{~km}$ and

3 the other beneath the northern slope de Ryukyu Arc at depth of $5 \mathrm{~km}$ (Figure 13h). These

4 anomalies do not strike parallel to the top of the slab as the high $V p / V s$ anomaly observed in

$5 \quad$ Profiles L1 and L2 is doing between Yonaguni and Kueishantao Islands.

6 A 3-D view of the high $V p / V s$ distributions is shown in Figure 14. The E-W section lies 7 along the southern OT central graben. The two series of high $V p / V s$ bodies are imaged by 8 arrows (a) (group 1; Figure 12a) and (b) (group 2; Figure 12b). As mentioned above, the $9 \quad V p / V s$ distribution patterns on each side of the slab tear are different. The first group of anomalies is restricted to the west of the slab tear (arrows a). A different pattern is observed close to the slab tear: west of it, a high $V p / V s$ anomaly rises northerly from 50-km-deep in 12 direction of the southern OT central graben and extends northward at shallow depths (Profile L3; Figures 13f); east of it, almost all the crust and the mantle wedge are characterized by high $V p$, Vs and low Vp/Vs (Profile L4; Figure 13g).

\section{3. Seismicity and Tomographic Features}

Earthquakes used in this inversion have been grouped into four clusters (clusters 1, 2, 3a and 3b, Figure 2) (Lin et al., 2006, revised). Most of the earthquakes in clusters 1 and 2 are distributed around the boundary of low $V p$, Vs and high $V p / V s$ anomalies (Figures 6 to 8). Earthquakes of clusters $3 \mathrm{a}$ and $3 \mathrm{~b}$ are located in the area of low $\mathrm{Vp} / \mathrm{Vs}$ distribution (Figure 8). The same observations can be made on the five profiles L1 to L5 (Figure 13). Profiles L2 cuts across the CBVT area and cluster 1 . The earthquakes are concentrated around the high $V p / V s$ boundaries, but most of the earthquakes displayed on Profiles L4 and L5 are distributed within the area of high $V p$, $V s$ and low $V p / V s$. If the high $V p / V s$, low $V p$ and low $V s$ bodies are $\mathrm{H}_{2} \mathrm{O}$-enriched and/or melt, earthquakes occur on the edge of these bodies, which might 
1 delineate the contours of magma chambers (Figures 6 to 8). East of the slab tear (Profile L5),

2 high $V p / V s$, low $V p$ and $V s$ bodies are not identified, suggesting that a melt fraction or an

$3 \mathrm{H}_{2} \mathrm{O}$-enriched component is absent. Normal faulting is consequently the only mechanism

4 which controls the shallow earthquake activity east of the slab tear and accounts for the

5 extension in the continental lithosphere.

6 To summarize, two bodies characterized by high $V p / V s$, low $V p$ and low $V s$ were

7 identified: (1) An inclined and continuous chip-like high $V p / V s$, low $V p$ and low $V s$ body 8 starts at a depth of about $40 \mathrm{~km}$ beneath the northern OT margin, propagates parallel to the top 9 of the Ryukyu slab, and becomes shallower in direction of the OT axis (Figure 12a and arrows a in Figure 14). This anomaly starts from the upper mantle and rises in direction of the 11 southern part of the southern OT central graben, but is restricted to west of the slab tear. (2) 12 Starting at a depth of $50 \mathrm{~km}$ near $24.2^{\circ} \mathrm{N}, 123.2^{\circ} \mathrm{E}$, a high $V p / V s$ anomaly rises obliquely from the Ryukyu slab tear to the subsurface, along a channel which is divided into three subchannels (Figure 12b and arrow b in Figure 14). One channel rises northerly through the mantle wedge in direction of the CBVT area. This oblique feature suggests that the magmatic origin of the CBVT is linked to the fluid and/or melt rising from the slab tear as already proposed by Lin et al. (2004a). A second branch extends from the Ryukyu slab to north of Iriomote Island. The third one rises northerly above the slab tear and terminates at a depth of $15 \mathrm{~km}$ beneath the northern slope of the southwestern OT. Earthquakes linked to the magmatic activities are concentrated around the boundary of high $V p / V s$ and low $V p$, $V s$ anomalies (magma chamber of clusters 1 and 2). For clusters 3a and 3b, earthquakes located in areas characterized by high $V p, V s$ and low $V p / V s$ distribution are dominant. This observation suggests that main factors controlling the tectonic activities on each side of the slab tear are different. 
The integration of traveltime data from the Taiwanese and Japanese networks has been

2 already attempted in the past (Hsu, 2001; Nakamura et al., 2003), imaging large-scale features.

3 However, the westernmost part of the Ryukyu slab was not clearly imaged. Recently, Chou et

4 al. (2006) have combined data from two networks and relocated more than 5000 earthquakes.

5 The shape of the Ryukyu slab obtained from this relocated hypocenter distribution shows a

6 continuous slab configuration from $121.5^{\circ} \mathrm{E}$ to $124^{\circ} \mathrm{E}$ longitude and a folding of the slab

7 around $123^{\circ} \mathrm{E}$ rather than a slab tear as proposed by Deschamps et al. (2000). There is

8 consequently a debate concerning the existence of a slab folding or a slab tear. In the absence

9 of well-located slab earthquakes down to $150 \mathrm{~km}$, indirect arguments support the two hypotheses. In favor of a slab folding, (i) fluid dehydrated from an anomalously hydrated part of the slab as the subducted Gagua Ridge may escape from the slab and be entrained with the motion of the slab until it reaches a depth where it fluxes in the mantle wedge at $125-150 \mathrm{~km}$. This melt/fluid may then rise as a return flow in the mantle wedge (Hasegawa and Nakajima, 2004; Reyners et al., 2006). (ii) As Deschamps et al. (2000) point out, the thickness of the crust of the subducted Huatung basin west of $123.3^{\circ} \mathrm{E}$ longitude is twice that of normal crust ( $\sim 12 \mathrm{~km}$ instead of $6 \mathrm{~km}$ ). One would thus expect more fluids to be dehydrated from this thicker crust. A crust twice as thick that normal will have four times the thermal time constant (Kirby et al., 1996), meaning that fluid will be dehydrated deeper, where it will be more efficient in fluxing melt in the mantle wedge. So the thicker crust west of $123.3^{\circ} \mathrm{E}$ may be a candidate for the higher $V p / V s$ and larger magma productivity. However, these hypotheses do not explain the presence of the high $V p / V s$ and low $V p$, Vs source at a depth of $50 \mathrm{~km}$ along $123.3^{\circ} \mathrm{E}$ from beneath the slab roof (Fig. 12b), which spans and is divided upward in the mantle wedge. Though it is not a crucial point for the interpretation of our tomographic results, we suggest that the detailed tomographic results shown in this study are in favor of a slab tear rather than of a slab folding for two reasons: the volcanic material has a deep slab component 
1 (Shinjo et al., 1999) connected to the slab at $123.3^{\circ} \mathrm{E}$ longitude and the origin at a depth of

2 only $50 \mathrm{~km}$ of the high $V p / V s$, low $V p$ and $V s$ bodies along $123.3^{\circ} \mathrm{E}$ longitude but from

3 underneath the slab roof, which excludes a Gagua Ridge dehydration origin. In the following

4 sections, we will discuss the origin of these deep features as linked to a slab tear rather than a

5 slab bending and their relation with the volcanic activity.

\section{1. Asthenospheric Intake}

In the northeast Japan arc, several hot "fingers" characterized by low $V p$ and $V s$ velocities within the mantle wedge were imaged by tomography and were interpreted as conduits of magma supplies to the Quaternary volcanoes (Tamura et al., 2002) corresponding to the dehydration of the slab and/or the underlying hydrous mantle (Park and Nyblade, 2006; Waite et al., 2006). Kincaid and Hall (2003) also show that the combination of increasing slab dip and backarc spreading coincides with a rapid steepening of path line trajectories for the material feeding the wedge corner and a marked increase in decompression melting within the wedge. This suggests that some magmas could have been generated within the mantle wedge. We proposed that the inclined chip-like high $V p / V s$ body imaged in Figure 12a might represent the intake of asthenosphere linked to the rapid slab retreat (Heki, 1996; Imanishi et al., 1996) and generated by the asthenospheric material flowing around the Ryukyu slab edge and the $123.3^{\circ} \mathrm{E}$ slab tear. Consequences of lateral mantle flows around the slab edge from underneath the slab towards the mantle wedge would induce a slab rollback near the slab lateral edge, increasing the amount of extension (Schellart et al., 2002 and 2007; Heuret and Lallemand, 2005). In our tomographic results, low $V p, V s$ and high $V p / V s$ anomalies are absent east of $123.3^{\circ} \mathrm{E}$. This difference in tomographic results on each side of the slab tear might be due to the difference in slab dips (Deschamps et al., 2000; Lin et al., 2004a), increasing the amount of asthenospheric material rising up west of the slab tear. 
The other factor at the origin of the low $V p$, $V s$ and high $V p / V s$ anomalies in the mantle

2 wedge might be linked to an increase of temperature. In laboratory experiments, the mantle

3 flow around slab edges and its effect on surface temperatures of slabs have been modeled

4 both for a fixed slab position and a slab rollback. The subduction of slabs in a fixed position

5 leads to heating of the slab ends with respect to the slab centers. Conversely, rollback of slabs

6 induces flow around slab edges and heating of slab centers with respect to slab edges (Kincaid

7 and Griffiths, 2003). As the CBVT is located in the central part of the sub-plate bounded by

8 the slab edge at $121.8^{\circ} \mathrm{E}$ longitude in the west and by the slab tear along the $123.3^{\circ} \mathrm{E}$ meridian

9 in the east, the heating effect might be more pronounced in the area of the CBVT rather than

10 close to the slab edges. Hence, this relative increase in temperature might also explain the low

11 velocities and the high $V p / V s$ anomalies in the mantle wedge.

12

\section{2. Mantle Flow Around the Slab Edge and Through the Slab Tear}

Mount Etna (Sicily), located above the southern edge of the Ionian subducting lithosphere, lies on the continental crust and is close to the subduction-related Aeolian volcanic arc. It shows ocean basalt affinities (Barberi, 1974; Condomines et al., 1982). Gvirtzman and Nur (1999) suggested that Mount Etna is not fed by material coming from the mantle wedge, but by the "suction" process of asthenospheric material from underneath the neighboring African plate. Such lateral flow is expected when descending slabs (rollback) create a low-pressure region behind them. As the subducting slab is retreating, the motion of the underlying asthenosphere is forced sideways in particular around the slab edge. According to the seismic anisotropy, the magma production rate and the geochemical tracing, such lateral mantle inflows come from outside the arc-basin system into the mantle wedge (Turner and Hawkesworth, 1998; Smith et al., 2001; Civello and Margheriti, 2004).

Based on fluid dynamical experiments, rollback-induced flow modeling shows a dominant 
1 toroidal motion with two elliptic flow cells illustrating that the material initially located

2 beneath the slab is flowing around the lateral slab edges in the overlying mantle wedge. The

3 rotation axes of the flow cells are not vertical but tilted, with their axes oriented subparallel to

4 the lateral edges of the slab (Schellart, 2004). Thus, the mantle flow around the edge of a

5 subduction slab juxtaposes cold and hot materials of the subduction system and allows the

6 ingress of underlying mantle into the mantle wedge. Slab edge environments are therefore

7 characterized by volcanic products whose compositions are anomalous with respect to those

8 of volcanic arcs: adakites (partial melts of basaltic slabs, Yogodzinski et al., 2001), boninites

9 (partial melts of normally refractory mantle, Deschamps and Lallemand, 2003) and alkaline basalts (partial melts of enriched mantle, DeLong et al., 1975; Thirlwall et al., 1996).

At the two ends of the South Sandwich subduction system, the convergence of the arc and the backarc spreading center results in a greater subduction component into backarc lavas 13 (Taylor and Martinez, 2003). The observed enhanced magma supply results from the ingress of mantle flowing around the edge of the subducting South Sandwich slab as shown by seismic, gravity and geochemical data (Livermore et al., 1997; Bruguier and Livermore, 2001; Leat et al., 2004). Two closeby seamounts may also be fed by mantle flowing into the wedge from the edge of the slab (Leat et al., 2004).

In the Middle Okinawa Trough, the volcanic rocks only present a very light subduction component (Shinjo, 1999). The strongest subduction components and the largest volume of volcanic products appear in the southwestern OT (Shinjo et al., 1999, 2003a and 2003b; Chung et al., 2000). In the southern OT system, as for the South Sandwich subduction zone, there is no evidence that the basaltic part of the slab edge has melted and produced adakites, as proposed for the Pacific plate edge subducting beneath Kamchatka (Yogodzinski et al., 2001). Instead, according to the geochemical analyses of rocks collected in the southern OT, subducting sediments melted beneath the CBVT are highlighted (Chung et al., 2000; Shinjo et 
1 al., 2003a and 2003b). The volcanic rocks collected there vary in composition from basalts to

2 rhyolites and belong to the medium-K field. Shinjo et al. (2003a and 2003b) show that the

3 mafic intrusions of the CBVT rhyolites result from magma mixing between high temperature

4 mafic (high-Mg content) and low temperature felsic (low-Mg content) magmas, implying a

5 high degree of partial melting with slab components.

The northerly rising high $V p / V s$ and low $V p$, $V s$ anomalies imaged in Figure 12b start from underneath the slab at a depth of $50 \mathrm{~km}$, passes through the slab tear with a elliptic flow cell form, and then rises upward and westward to the surface. These anomalies might represent the upwelling of hot underlying $\mathrm{PH}$ lithospheric mantle through the Ryukyu slab tear and a subsequent increase of dehydration components and subduction fluxes. These processes may drive a significant subduction component into the backarc magmas, inducing subductiongenerated volatiles and a large magma supply in the backarc basin.

To summarize, two important processes for the magma genesis in the southern OT are imaged by the $V p$, $V s$ and $V p / V s$ tomographic images: the intake of the asthenosphere due to the southward retreat of slab (the inclined chip-like high $V p / V s$ body) and the mantle inflows around the Ryukyu slab edge (toroidal high $V p / V s$ inflows) and the Ryukyu slab tear. These processes might increase the dip of the western portion of the slab, contributing to open a window for mantle inflows through the slab tear. In the sketch of Figure 15, we suggest that the $\mathrm{H}_{2} 0$-rich component and/or melt would be formed through the slab tear and conveyed into the mantle wedge as a result of the high velocity retreat of the western portion of the slab (arrows 1). This mantle flow, driven by the westward PH motion with respect to EU, might propagate eastward in direction of Iriomote Island (arrow 2). In addition, slab rollback would induce the asthenosphere intake (arrows 3). Flow of mantle material may occur around the torn edge of the Ryukyu subduction slab, into the source region of backarc magmas, increasing the magma supply in the two volcanic areas (Kueishantao Island and CBVT, 


\section{Conclusions}

Based on a passive OBS experiment performed in the southern OT, more than 3300 microearthquakes were localized. Numerous high quality arrivals of $P$ - and $S$ - wave picked from this dataset allow us to construct detailed tomographic images in the southern OT and to propose the following conclusions:

(1) The fluid and/or melt is rising obliquely from a depth of $50 \mathrm{~km}$ through the slab tear in Iriomote Island $\left(24.5^{\circ} \mathrm{N} ; 123.9^{\circ} \mathrm{E}\right)$ and a third branch rises northerly above the slab tear up to a depth of $15 \mathrm{~km}$.

(2) An inclined chip-like high $V p / V s$ and low $V p$, Vs body dipping northerly represents the asthenospheric intake as a consequence of the slab retreat.

(3) Two mantle source components were imaged: The asthenospheric intake and the lateral inflows passing around the slab edge and through the slab tear. These two processes are triggered by the rollback of the slab, forcing mantle inflow into the mantle wedge around the slab edge and through the slab tear. We suggest that hydrous fluxing related to the lateral inflows has pervasively modified the convecting asthenospheric mantle flow beneath the southern OT. The enhanced magma in Kueishantao Island and the CBVT would be linked to these two processes.

(4) West of the slab tear, most of the earthquakes are located around the magma chambers, suggesting that the seismicity is linked to underlying magmatic and/or fluid activities. East of the slab tear, earthquakes are concentrated in an area characterized by high $V p$ and Vs velocities and low $V p / V s$. This peculiar distribution suggests the absence of magma chambers in this area and that normal faulting is the main factor controlling 
the distribution of earthquakes.

\section{Acknowledgments}

4

We thank the captain and crew of the R/V Ocean Research I for their help during the deployment of the Ifremer OBS instruments and the Central Weather Bureau (CWB) of

6 Taiwan and the Japan Meteorological Agency (JMA) for providing the land station data. The

7 GMT software package was used to draw some of the figures (Wessel and Smith, 1991). This work is part of an ongoing cooperative project between France and Taiwan encouraged and supported by Ifremer, the Institut Français de Taipei and the National Science Council of Taiwan. We particularly thank the two anonymous reviewers who made significant contributions concerning in particular the discussion of a slab tear versus a slab folding along the $123.3^{\circ} \mathrm{E}$ meridian.

\section{References}

Auffret, Y., P. Pelleau, F. Klingelhoefer, J. Crozon, J.-Y. Lin and J.-C. Sibuet (2004). MicrOBS: A new ocean bottom seismometer generation. First Break, 22, 41-47.

Barberi, F. et al. (1974). Evolution of a section of the African-Europe plate boundary: Paleomagnetic and volcanological evidence from Sicily. Earth Planet. Sci. Lett., 21, 269-

Bruguier, N. J. and R. Livermore (2001). Enchanced magma supply at the southern East Scotia Ridge: Evidence for mantle flow around the subducting slab? Earth Planet. Sci. Lett., 191, 129-144.

Civello, S. and L. Margheriti (2004). Toroidal mantle flow around the Calabrian slab (Italy) from SKS splitting. Geophys. Res. Lett., 31, L10601, doi:10.1029/2004GL019607, 2004. 
Taiwan-Ryukyu subduction-collision complex: Folding of a viscoelastic slab and the double seismic zone. J. Geophys, Res., 111, B04410, doi:10.1029/2005JB003822.

3 Chung, S.-L., S.-L. Wang, R. Shinjo, C.-S. Lee and C.-H. Cheng (2000). Initiation of arc magmatism in an embryonic continental rifting zone of the southernmost part of Okinawa Trough. Terra Nova, 12, 225- 230.

Condomines, M., J. C. Tanguy, G. Kieffer and C. J. Allègre (1982). Magmatic evolution of a volcano studied by $230^{\mathrm{Th}} / 238^{\mathrm{U}}$ disequilibrium and trace elements systematics: The Etna case. Geochim. Cosmochim. Acta, 46, 1397-1416.

DeLong, S. E., F. N. Hodges and R. J. Arculus (1975). Ultramafic and mafic inclusions, Kanaga Island, Alaska, and the occurence of alkaline rocks in island arcs. J. Geol. Soc. China, 83, 721-736.

Deschamps, A. and S. Lallemand (2003). Geodynamic setting of Izu-Bonin-Mariana boninites. in: R.D. Larter, P.T. Leat (Eds.), Intra-Oceanic Subduction Systems: Tectonic and Magmatic Processes, Geol. Soc. London Spec. Publ., 219, 163-185.

Deschamps, A., P. Monié, S. E. Lallemand, S.-K. Hsu, and K. Y. Yeh (2000), Evidence for early Cretaceous oceanic crust trapped in the Philippine Sea plate, Earth Planet. Sci. Lett., 179, 503-516.

Eberhart-Phillips, D. (1986). Three-dimensional velocity structure in northern California Coast Range from inversion of local earthquake arrival times. Bull. Seism. Soc. Am., 76, 1025-1052.

Eberhart-Phillips, D. (1990). Three-dimensional P and S velocity structure in the Coalinga region, California. J. Geophys. Res., 95, 15,343-15,363.

Engdahl, E. R., R. D. Van der Hilst and R. P. Buland (1998). Global teleseismic earthquake relocation with improved travel times and procedures for depth determination. Bull. 
1 Font, Y., S. Lallemand and J. Angelier (1999). Etude de la transition entre l'orogène actif de

2 Taiwan et la subduction des Ryukyu - Apport de la sismicité. Bull. Soc. Géol. Fr., 170, 271- 283.

Gvirtzman, Z. and A. Nur (1999). The formation of Mount Etna as the consequence of slab rollback. Nature, 401, 782-785.

Haslinger, F. (1999). 3D crustal structure from local earthquake tomography around Gulf of Arta (Ionian region, NW Greece). Tectonophysics, 304, 210-218.

Heki, K. (1996). Horizontal and vertical crustal movements from three-dimensional very long baseline interferometry kinematic reference frame; implication for the reversal timescale revision. J. Geophys, Res., 101, 3187-3198.

Heuret, A. and S. Lallemand (2005). Plate motions, slab dynamics and back-arc deformation. Physics Earth and Planet. Interiors, 149, 31-51.

Hirata, N., H. Kinoshita, H. Katao, H. Baba, Y. Kaiho, S. Koresawa, Y. Ono and K. Hayashi southern Okinawa Trough. Bull. Earthquake Res. Inst., Tokyo Univ., 66, 37-70.

Hsu, S.-K., J.-C. Sibuet, S. Monti, C.-T. Shyu and C.-S. Liu (1996). Transition between the Okinawa Trough backarc extension and the Taiwan collision: New insights on the southernmost Ryukyu subduction zone. Mar. Geophys. Res., 18, 163-187.

Hsu, S.-K. (2001). Subduction/collision complexities in the Taiwan-Ryukyu junction area: Tectonics of the northwestern corner of the Philippine Sea plate. Terr. Atm. Oc. Sci., Supplementary Issue, 209-230.

Hsu, S.-K., J.-C. Sibuet and C.-T. Shyu (2001). Magnetic inversion of the East China Sea and Okinawa Trough: Tectonic implications. Tectonophysics, 333, 111-122.

Husen, S., E. Kissling and E. R. Flueh (2000). Local earthquake tomography of shallow subduction in north Chile: A combined onshore and offshore study. J. Geophys, Res., 105, 
Imanishi, M., F. Kimata, N. Inamori, R. Miyajima, T. Okuda, M. Takai and K. Hirahara (1996). Horizontal displacements by GPS measurements at the Okinawa-Sakishima islands (1994-1995). Zisin 2, 49, 417-421.

Ito, H., J. De Vilbiss and A. Nur (1979). Compressional and shear waves in saturated rock during water-steam transition. J. Geophys. Res., 84, 4731-4735.

Kincaid, C. and R. W. Griffiths (2003). Laboratory models of the thermal evolution of the mantle during rollback subduction. Nature, 425, 58-62.

Kincaid, C. and P. S. Hall (2003). Role of backarc spreading in circulation and melting at subduction zones. J. Geophys, Res., 108, B5, 2240, doi;10.1029/2001JB001174.

Kissling, E., W. L. Ellsworth, D. Eberhart-Phillips and U. Kradolfer (1994). Initial reference models in local earthquake tomography. J. Geophys, Res., 99, 19635-19646.

Koper, K. D., D. A. Wiens, L. M. Dorman, J. A. Hildebrand and S. C. Webb (1999). Constraints on the origin of slab and wedge anomalies in Tonga from the ratio of $\mathrm{S}$ and $\mathrm{P}$ anomalies. J. Geophys, Res., 104, 15089-15104.

Lallemand, S. and C.-S. Liu (1998). Geodynamic implications of present-day kinematics in the southern Ryukyu. J. Geol. Soc. China, 41, 551-564.

Leat, P. T., J. A. Pearce, P. F. Barker, I. L. Millar, T. L. Barry and R. D. Larter (2004). Magma genesis and mantle flow at a subducting slab edge: The South Sandwich arc-basin system.

Lee, Y. L. (2005). The study of active submarine volcanoes and hydrothermal vents in the Earth Planet. Sci. Lett., 227, 17-35.

Lee, C. S., G. J. Shor, L. D. Bibee, R. S. Lu and T. W. C. Hilde (1980). Okinawa Trough; Origin of a back-arc basin. Mar. Geol., 35, 219-241. southernmost part of Okinawa Trough (in chinese). Master thesis of the National Taiwan Ocean University, Taiwan, 45pp. 
1 Letouzey, J. and M. Kimura (1986). The Okinawa Trough genesis, structure and evolution of 2 a backarc basin developed in a continent. Mar. Petrol. Geol., 2, 111-130.

3 Levêque, J.-J., L. Rivera and G. Wittlinger (1993). On the use of the checkboard test to assess the resolution of tomographic inversion. Geophys. J. Int., 115, 313-318.

Lin, J.-Y., S.-K. Hsu and J.-C. Sibuet (2004a). Melting features along the Ryukyu slab tear, beneath the southwestern Okinawa Trough. Geophys. Res. Lett., 31: L19607, doi:10.1029/2004GL020862.

Lin, J.-Y., S.-K. Hsu and J.-C. Sibuet (2004b). Melting features along the western Ryukyu slab edge (northeast Taiwan) and Ryukyu slab tear (southernmost Okinawa Trough): Tomographic evidence. J. Geophys. Res., 109, B12402, doi:10.1029/2004JB003260.

Lin, J.-Y., J.-C. Sibuet, C. S. Lee, S.-K. Hsu, F. Klingelhoefer, Y. Auffret, P. Pelleau and J. Crozon (2006). Microseisismicity and faulting in the southwestern Okinawa Trough. Tectonophysics, revised.

Livermore, R., A. Cunningham, L. Vanneste and R. D. Larter (1997). Subduction influence on magma supply at the East Scotia Ridge. Earth Planet. Sci. Lett., 1977, 261-275.

Mavko, G. and T. Mukerji (1995). Seismic pore space compressibility and Gassman’s relation.

Miller, D. S. and R. B. Smith (1999). P and S velocity structure of the Yellowstone volcanic

Nakamura, M., Y. Yoshida, D. Zhao, H. Katao and S. Nishimura (2003). Three-dimensional 
1 Nishimura, S., M. Hashimoto and M. Ando (2004). A rigid block rotation model for the GPS

2 derived velocity field along the Ryukyu arc. Phys. Earth Planet. Inter., 142, 185-203.

3 Park, Y. and A. A. Nyblade (2006). P-wave tomography reveals a westward dipping low velocity zone beneath the Kenya Rift. Geophys. Res. Lett., 33, L07311, doi:10.1029/2005GL025605.

Reyners, M., D. Eberhart-Phillips, G. Stuart and Y. Nishimura (2006). Imaging subduction from the trench to $300 \mathrm{~km}$ depth beneath the central North Island, New Zealand, with Vp and Vp/Vs. Geophys. J. Int., 165(2), 565-583.

Schellart, W. P. (2004). Kinematics of subduction and subduction-induced flow in the upper mantle. J. Geophys, Res., 109, B07401, doi:10.1029/2004JB002970.

Schellart, W.P., J. Freeman, D.R. Stegman, L. Moresi, and D. May, Evolution and diversity of subduction zones controlled by slab width, Nature, 446, 308-311, 2007.

Schellart, W. P., G. S. Lister and M. W. Jessell (2002). Analogue modelling of asymmetrical back-arc extension. J. Vir. Expl., 7, 25-42.

Seno, T., S. Stein and A. E. Gripp (1993). A model for the motion of the Philippine sea plate with NUVEL-1 and geological data. J. Geophys, Res., 98, 17941-17948.

Shinjo, R. (1999). Geochemistry of high Mg andesites and the tectonic evolution of the Okinawa Trough-Ryukyu arc system. Chem. Geol., 157, 69- 88.

Shinjo, R., S.-L. Chung, Y. Kato and M. Kimura (1999). Geochemical and Sr-Nd isotopic characteristics of volcanic rocks from the Okinawa Trough and Ryukyu arc: Implications for the evolution of a young, intracontinental back arc basin. J. Geophys. Res., 104, 10,591- 10,608.

Shinjo, R., S. Hokakubo, S. Haraguchi, T. Matsumoto and J. Woodhead (2003a). Geochemical characteristics of volcanic rocks from the southern Okinawa Trough and its implications for tectono-magmatic evolution. Eos Trans. AGU, 84(46), Fall Meet. Suppl., Abstract 
2 Shinjo, R., S., S. Hokakubo, S. Haraguchi and T. Matsumoto (2003b). Regional variation in geochemistry of volcanic rocks from the southern Okinawa Trough (in Japanese). Earth Mon., 43, 21-26.

Sibuet, J.-C., B. Deffontaines, S.-K. Hsu, N. Thareau, J.-P. Le Formal and C.-S. Liu (1998). The southwestern Okinawa Trough back-arc basin: Tectonics and volcanism. J. Geophys. Res., 103, 30,245-30,267.

Sibuet, J.-C. and S.-K. Hsu (2004). How was Taiwan created? Tectonophysics, 379, 159-181.

Sibuet, J.-C., S.-K. Hsu, C.-T. Shyu and C.-S. Liu (1995). Structural and kinematic evolution of the Okinawa Trough backarc basin. in Backarc Basins: Tectonics and magmatism, edited by B. Taylor, Plenum, New York, 343-379.

Sibuet, J.-C., J. Letouzey, F. Barbier, J. Charvet, J.-P. Foucher, T. W. C. Hilde, M. Kimura, L.Y. Chiao, B. Marsset, C. Muller and J.-F. Stéphan (1987). Backarc extension in the Okinawa Trough. J. Geophys. Res., 92, 14041-14063.

Smith, G. P., D. A. Wiens, K. M. Fisher, L. M. Dorman, S. C. Webb and J. A. Hildebrand (2001). A complex pattern of mantle flow in the Lau backarc. Science, 292, 713-716.

Spakman, W. and G. Nolet (1998). Imaging algorithms, accuracy and resolution in delay time tomography. In Vlaar, N. J., Nolet, G. Wortel, M. J. R., Cloetingh, S. A. P. L. (Eds). Mathematical Geophysics. Reidel, Dordrecht, pp. 155-187.

Tamura, Y., Y. Tatsumi, D. Zhao, Y. Kido and H. Shukuno (2002). Hot fingers in the mantle wedge: New insights into magma genesis in subduction zones. Earth Planet. Sci. Lett., 197, 105-116.

Taylor, B. and F. Martinez (2003). Back-arc basin basalt systematics. Earth Planet. Sci. Lett., 210, 481-497.

Thirlwall, M. F., A. M. Graham, R. J. Arculus, R. S. Harmon and C. G. Macpherson (1996). 
Resolution of the effects of crustal assimilation, sediment subduction, and fluid transport in island arc magmas; Pb-Sr-Nd-O isotope geochemistry of Grenada, Lesser Antilles. Geochim. Cosmochim. Acta, 60, 4785-4810.

Thurber, C. H. (1993). Local earthquake tomography: Velocities and Vp/Vs-theory. in Seismic Tomography: Theory and Practice, edited by H. M. Iyer and K. Hirahara, Chapman and Hall, New York, pp. 563- 583.

Thurber, C. H. and D. Eberhart-Phillips (1999). Local earthquake tomography with flexible gridding. Comput. Geosci., 25, 809-818.

Turner, S. and C. Hawkesworth (1998). Using geochemistry to map mantle flow beneath the Lau Basin. Geology, 26, 1019-1022.

Waite, G. P., R. B. Smith and R. M. Allen (2006). Vp abd Vs structure of the Yellowstone hot spot from teleseismic tomography: Evidence for an upper mantle plume. J. Geophys, Res.,

Wang, K.-L., S.-L. Chung, C.-H. Chen, R. Shinjo, T.-F. Yang and C.-H. Chen (1999). Post-

$$
\text { 111, B04303, doi:10.1029/2005JB003867. }
$$

$$
\text { collisional magmatism around northern Taiwan and its relation with opening of the }
$$
Okinawa Trough. Tectonophysics, 308, 363-376.

Wang, T.-K., K. McIntosh, Y. Nakamura, C.-S. Liu and H.-W. Chen (2002). Velocity-interface structure of the southwestern Ryukyu subduction zone from EW9509-1 OBS/MCS data. Mar. Geophys. Res., 22, 265-287.

Watanabe, T. (1993). Effects of water and melt on seismic velocities and their application to characterization of seismic reflectors. Geophys. Res. Lett., 20, 2933-2936.

Wessel, P. and W. M. F. Smith (1991). Free software helps map and display data. EOS, Trans., Am. Geophys. Union, 72, 441-446.

Wyss, M., A. Hasegawa and J. Nakajima (2001). Source and path of magma for volcanoes in the subduction of northeastern Japan. Geophys. Res. Lett., 28, 1819-1822. 
1 Yogodzinski, G. M., J. M. Lees, T. G. Churikova, F. Dorendorf, G. Woerner and O. N. Volynets

2 (2001). Geochemical evidence for the melting of subducting ocean lithosphere at plate edges. Nature, 409, 500-504.

Yu, S.-B., H. Y. Chen and L.-C. Kuo (1997). Velocity field of GPS stations in the Taiwan area. Tectonophysics, 274, 41-59.

Zelt, C. A. (1998). Lateral velocity resolution from three-dimensional seismic refraction data. Geophys. J. Int., 135, 1101-1112.

Zhao, D., O. P. Mishra and R. Sanda (2002). Influence of fluids and magma on earthquakes: Seismological evidence. Physics Earth and Planet. Interiors, 132, 249-267.

\section{Figure Captions}

Figure 1: Tectonic framework of the Ryukyu arc and backarc system. The arrow indicates the Philippine Sea plate motion relative to Eurasia (Seno et al., 1993). The large gray line underlines the volcanic front. In inset (a), dots represent earthquake hypocenters (Engdahl et al., 1998). The black contour lines are depths of the Wadadi-Benioff zone (adapted from Font et al. (1999) in the western part). The white dashed line shows the location of the slab tear (Lin et al., 2004a and 2004b). The locations of the Ryukyu trench and Okinawa Trough normal faults are from Sibuet and Hsu (2004). In inset (b), detailed bathymetry (isobath spacing, $100 \mathrm{~m}$ ) of the cross-backarc volcanic trail (CBVT) (Sibuet et al., 1998) located in the gray square box of inset (a).

Figure 2: Hypocenters of 2823 microearthquakes recorded in the southwestern Okinawa Trough by the OBS network during 12 days and relocated with the SIMUL2000 program (Thurber and Eberhart-Phillips, 1999). The four rectangles correspond to the location of the earthquake clusters $(1,2,3 a$ and $3 b)$. The size of dots is function of the magnitude. Colors show the depth ranges. Bathymetric contours every $100 \mathrm{~m}$ (Sibuet et al., 1998). 
The dashed line is the prolongation of the Lishan fault. The NW-SE oriented dasheddotted line underlines the northern boundary of clusters 1 and 2 and might correspond to an old structural trend (Hsu et al., 1996). Black triangles correspond to the locations of OBS stations and black squares to the surrounding land stations.

Figure 3: 2-D P-wave ray coverage shown by gray lines between earthquakes (dark gray dots) and seismic recording stations. The OBS (black triangles) recorded earthquakes during a period of 12 days (3353 events). Black squares are the locations of seismic land stations of the Central Weather Bureau and Japan Meteorological Agency networks. Bathymetric contours every $500 \mathrm{~m}$.

Figure 4: Results of checkboard test resolution displayed for eight horizontal slices ranging from depths of 5 to $60 \mathrm{~km}$. (a) Grid spacing of 45-60 km; (b) grid spacing of 15-20 km; and (c) flexible gridding method applied in areas of poor checkboard distribution. Slave and master grids are linked.

Figure 5: (a) Trade-off curve for $P$-wave velocity inversion; (b) trade-off curve for $V p / V s$ inversion. Numbers marked above black dots are damping values.

Figure 6: $V p$ tomography results displayed for eight slices from 5 to $60 \mathrm{~km}$. $V p$ values are in percentages with respect to the average $P$-wave velocity at the depth of the slice. White dashed lines show the locations where low $V p$, low $V s$ and high $V p / V s(>1.78)$ values are observed. The four rectangles correspond to the location of the four earthquake clusters. Black stars are the earthquakes used in the inversion at the depth of the slice $\pm 5 \mathrm{~km}$. Bathymetric contours in gray every $500 \mathrm{~m}$.

Figure 7: Vs tomography results displayed for eight slices from 5 to $60 \mathrm{~km}$. Vs values are in percentages with respect to the average $S$-wave velocity at the depth of the slice. Legend as in Figure 6. 
1 Figure 8: $V p / V s$ tomography results displayed for eight slices from 5 to $60 \mathrm{~km}$. Vp/Vs values are in percentages with respect to the average $\mathrm{Vp} / \mathrm{Vs}$ at the depth of the slice. Legend as in Figure 6.

Figure 9: Vp resolution (diagonal elements of the resolution matrix) displayed for eight slices from 5 to $60 \mathrm{~km}$. White dashed lines show locations where low $V p$, low $V s$ and high $V p / V s$ (> 1.78) values are observed. Black stars are the earthquakes used in the inversion.

Figure 10: $V p / V s$ resolution (diagonal elements of the resolution matrix) displayed for eight slices from 5 to $60 \mathrm{~km}$. Legend as in Figure 9.

Figure 11: Solution quality of $V p$ model using synthetic characteristic models. Results are shown for four horizontal slices. The initial starting models are constructed for low and high anomalies (-0.03 : inverted triangles and +0.03 : crosses). The computed resulting models are shown. White dashed lines are the locations of low $V p$, low $V s$ and high $V p / V s$ $(>1.78)$ values.

Figure 12: Geographical distribution of areas with $V p / V s$ values higher than 1.78 and low $V p$ and low Vs values, extracted from slices of Figures 6 to 8 and ranging from $10 \mathrm{~km}$ (light gray) to $50 \mathrm{~km}$ (dark gray). Dashed lines are the isobaths of the Wadati-Benioff zone (adapted from Font et al. (1999) in the western part). Light arrows show the upward propagation trends. V are the locations of detected hot vents (Lee, 2005). Tomographic profiles L1 to L5 are displayed in Figure 13. The large dashed line is the location of the slab tear. For clarity, results are displayed in two figures (a and b). The black square indicates the cross-backarc volcanic trail (CBVT).

Figure 13: Tomographic results along profiles L1 to L5 shown in the up-right location map and in Figure 12. Black stars are locations of earthquakes used for the inversion displayed in stripes of $\pm 10 \mathrm{~km}$ on each side of the profiles. White stars show the relocated 
earthquakes by Engdahl et al. (1998). (a) Comparison along profile L1 between our tomographic results with the $P$-wave velocity-interface model (black dashed lines, Wang et al., 2002). Labels of black dashed lines are the $V p$ values in $\mathrm{km} / \mathrm{s}$ (Wang et al., 2002). (b) and (c): Comparison between tomographic results obtained by Nakamura et al. (2003) and in this study along Profile L3. (d) to (h), tomographic results in percentages with respect to the average values. The light gray dashed line corresponds to the top of the slab. Red dashed lines represent the high $V p / V s$ body rising from the slab at a depth of $50 \mathrm{~km}$; red dotted lines represent the inclined and continuous high $V p / V s$ body parallel to the top of the Ryukyu slab. Arrows show the position of the southern Okinawa Trough (OT) central graben. RA: Ryukyu Arc; CBVT: Cross backarc volcanic trail.

Figure 14: 3-D block diagram showing cross-sections of $V p / V s$ ratios. The shaded 3-D topography is extracted from Sibuet et al. (1998). Short horizontal black segments are earthquake locations. Light arrows (a): the high $\mathrm{Vp} / \mathrm{Vs}$ bodies rise obliquely from the north in direction of the southern OT central graben and then are parallel to the top of slab. Contoured light arrows (b): a high $V p / V s$ body rises obliquely from the slab tear at a depth of $50 \mathrm{~km}$ in direction of the CBVT area and Iriomote Island. The gray dashed line shows the top of the slab. Two sets of arrows converge at 15-km-deep beneath the CBVT area.

Figure 15: Diagram showing the slab tear occurring in the northwestern corner of the Philippine Sea plate, along the northern prolongation of Gagua Ridge. Arrows (1) indicate inflow of mantle material induced by the rollback process around the slab edges. Stippled arrow (2) shows the eastern propagation of mantle inflow probably resulting from the continuous motion (8 cm/yr, Yu et al., 1997) of the Ryukyu slab with respect to Eurasia in the N306 ${ }^{\circ}$ direction. Arrows (3) show the direction of asthenosphere intake. The shaded area corresponds to the upwelling asthenospheric material. Contorted stippled arrow (4) gives an indication of the oblique fluid and/or melt pathways to Kueishantao Island (KI). 
Arrow (5) shows the enhanced magma formation in the CBVT area supplied by the

2 returned inflow (arrow 1) and/or by the intake of the mantle wedge (arrows 3). 


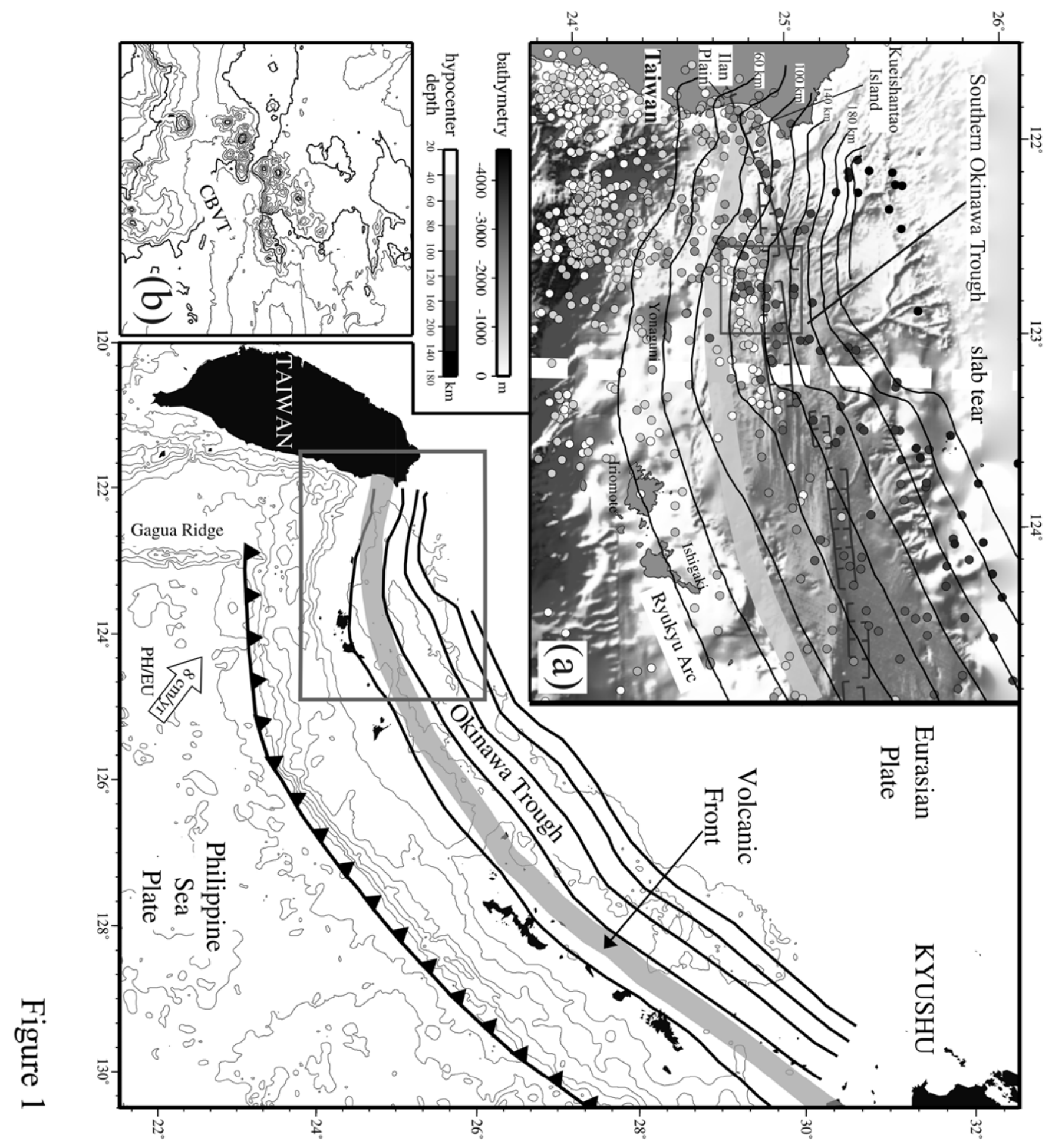




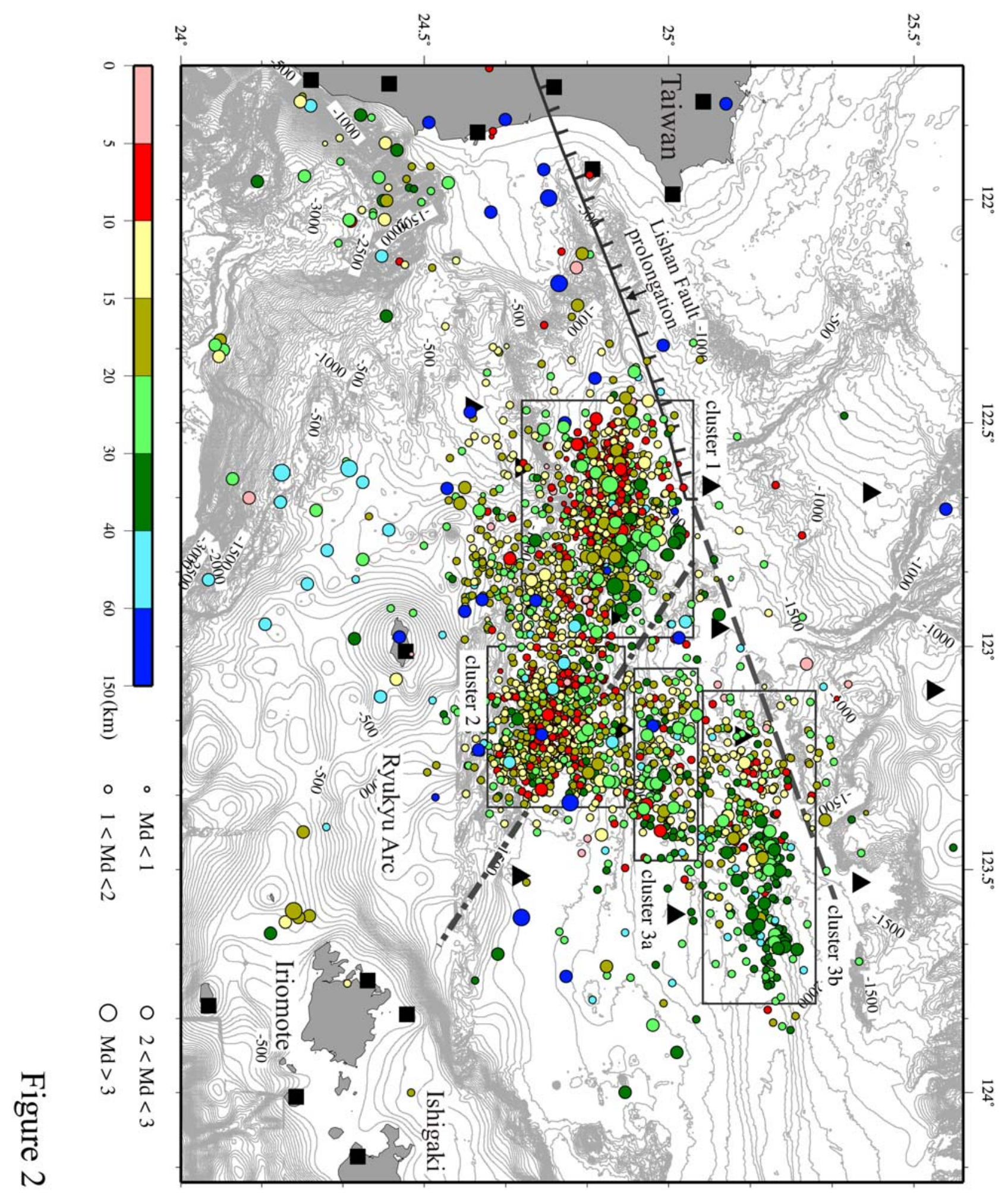




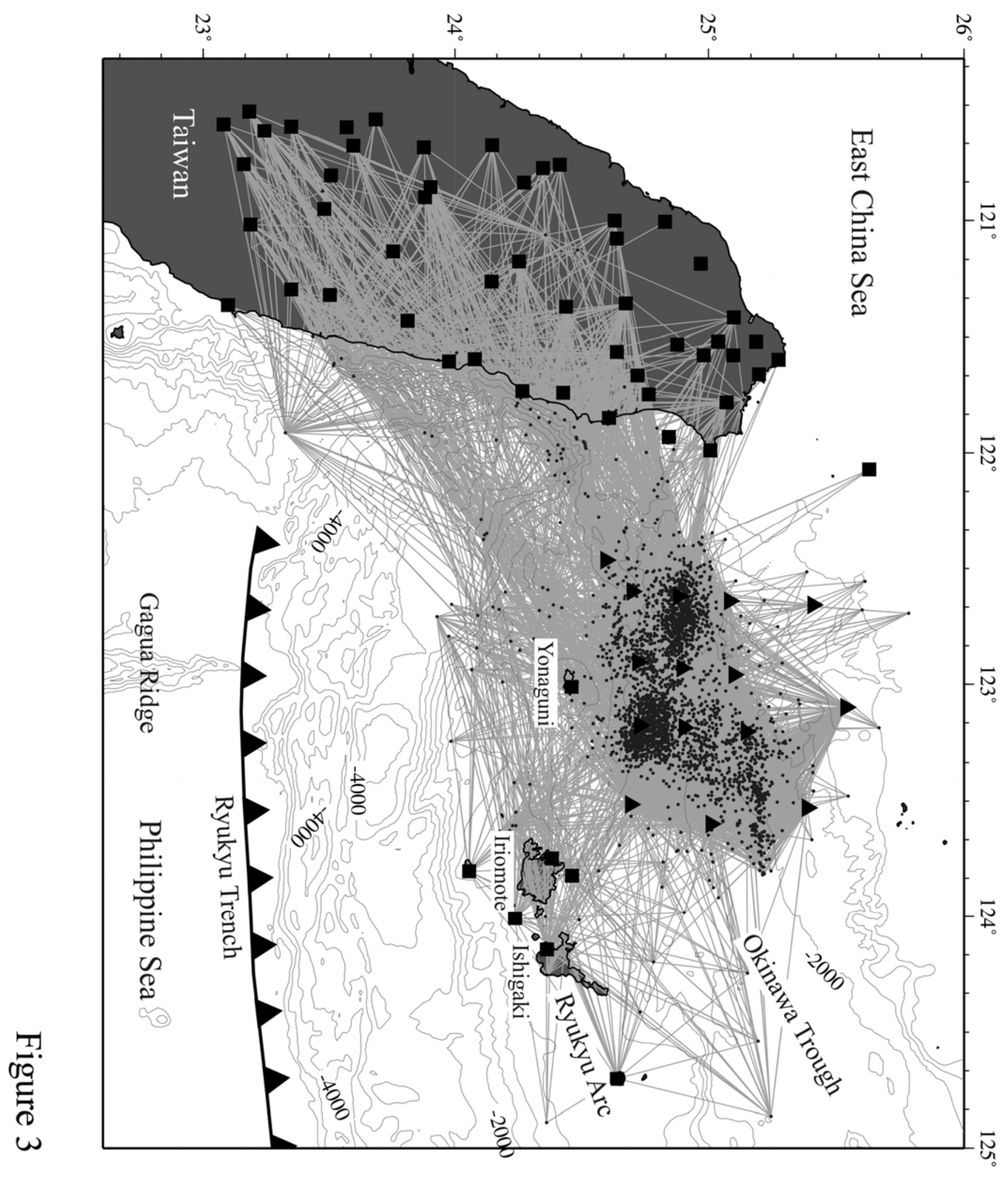



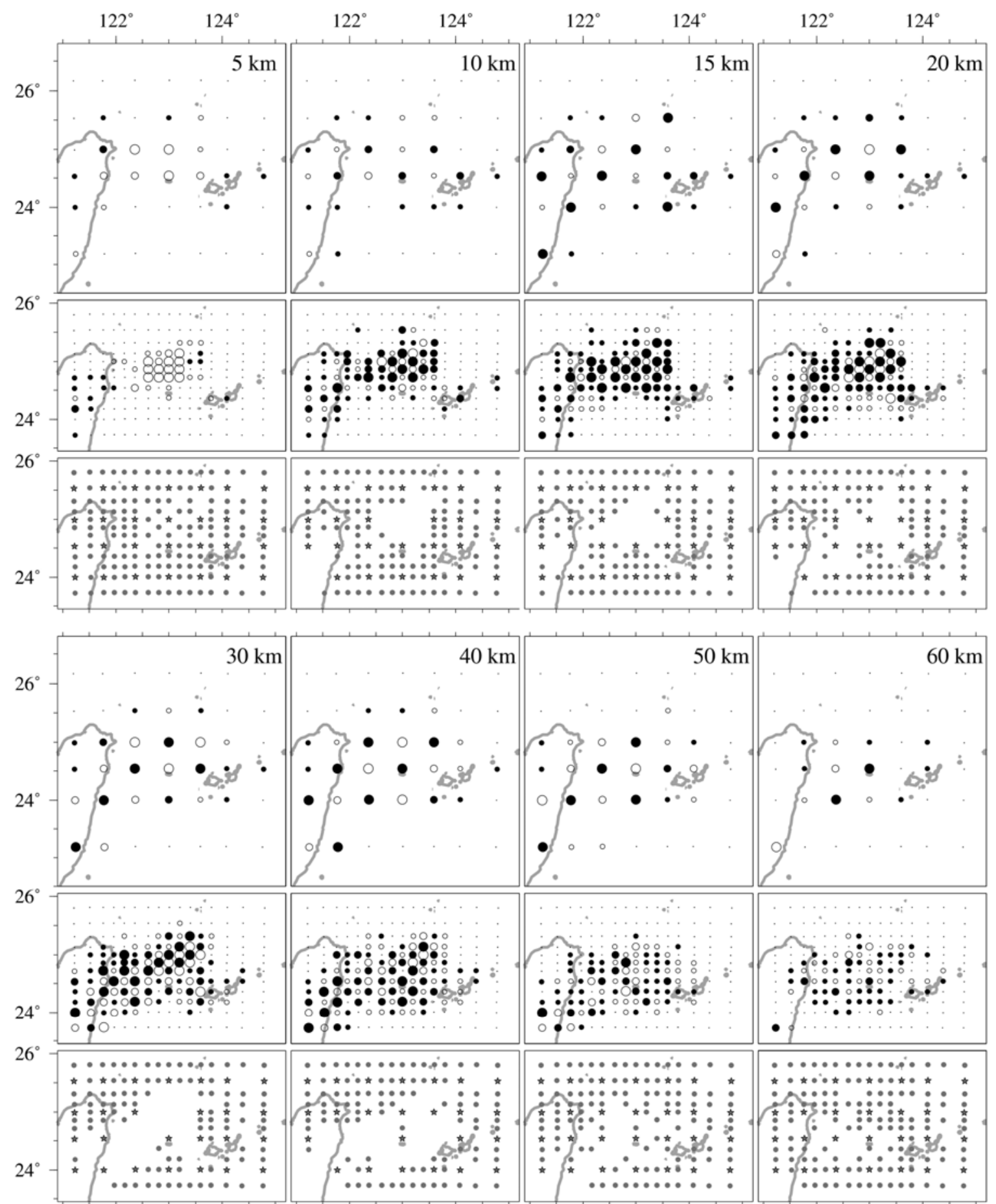

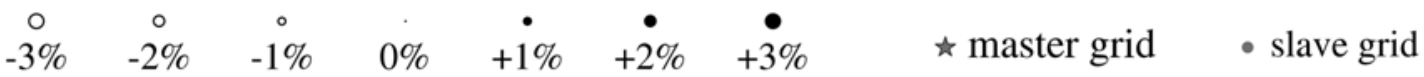

Figure 4 

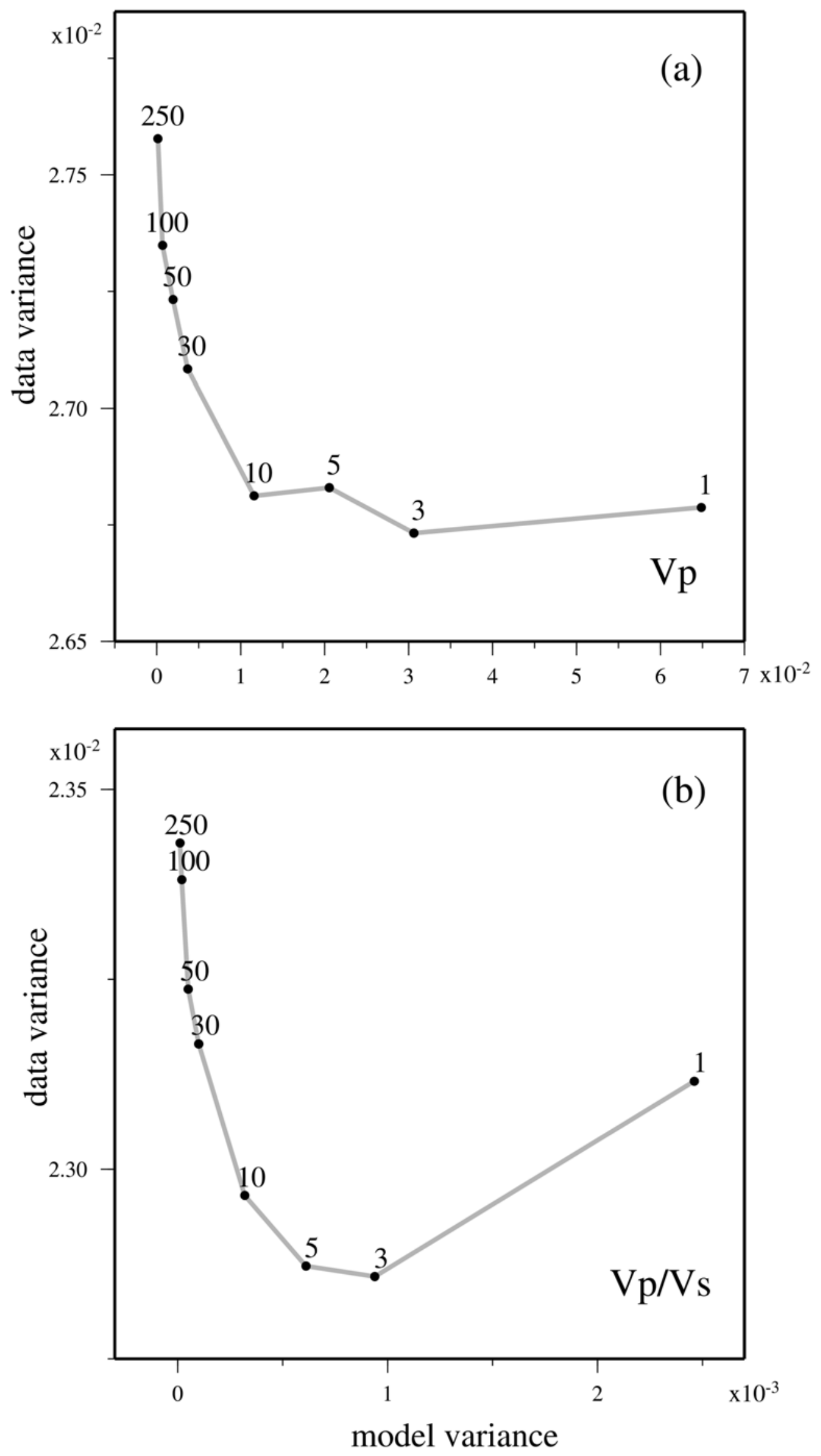

Figure 5 

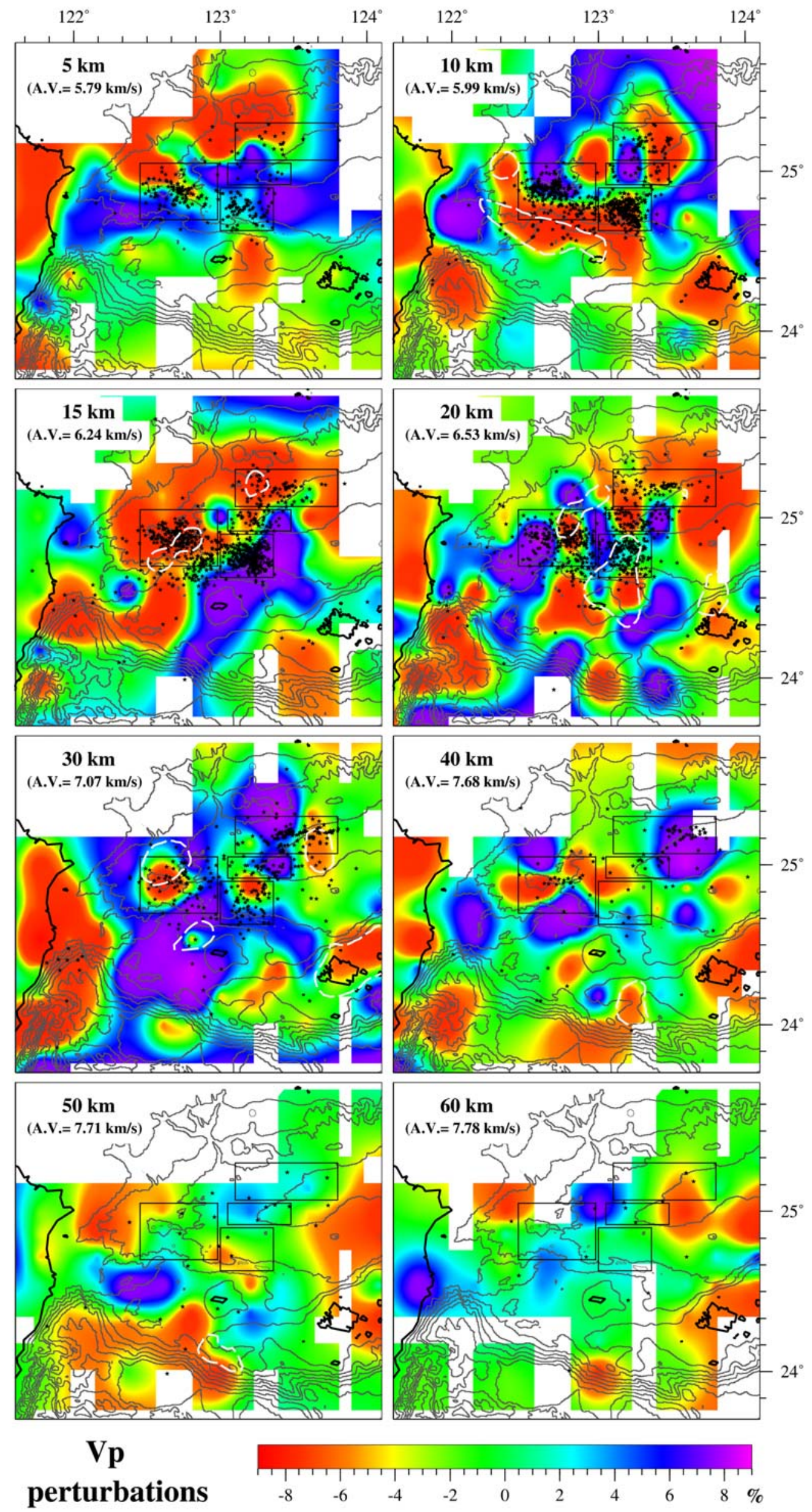

Figure 6 

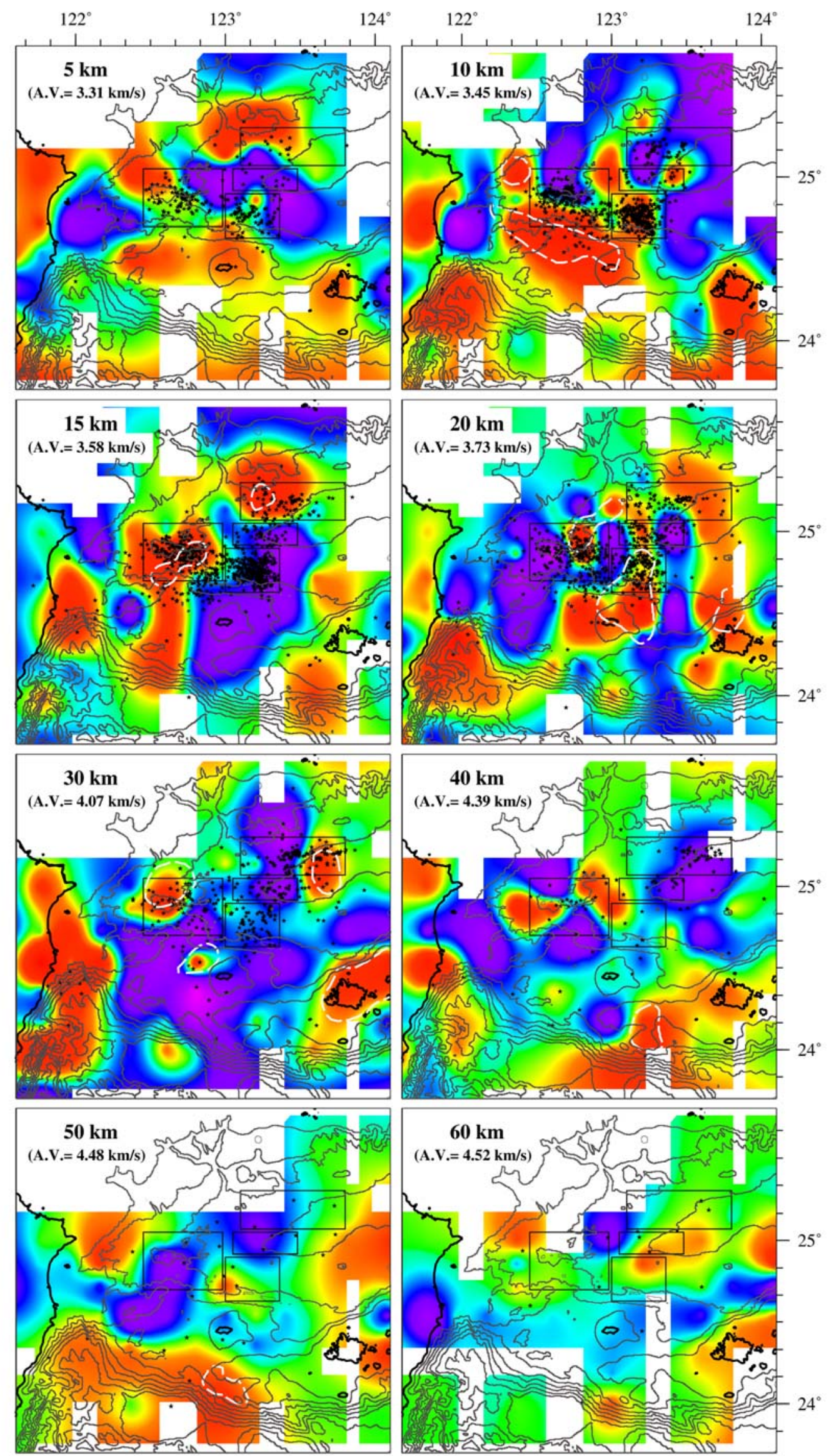

Vs

perturbations

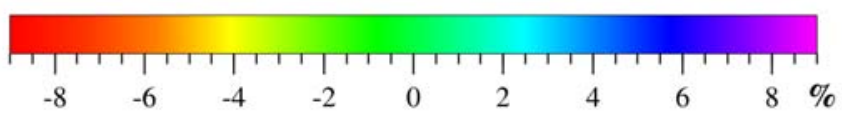

Figure 7 

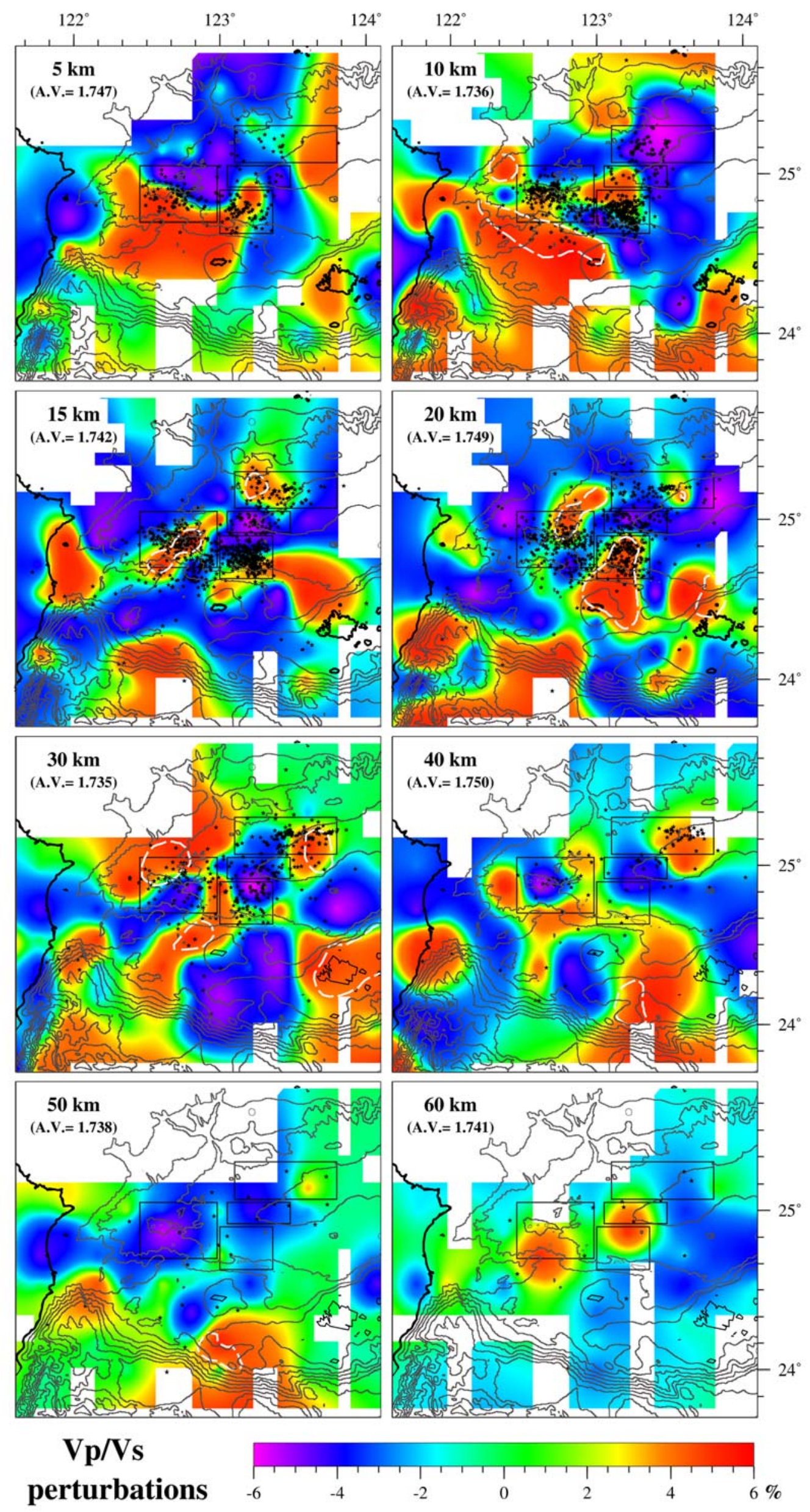

Figure 8 

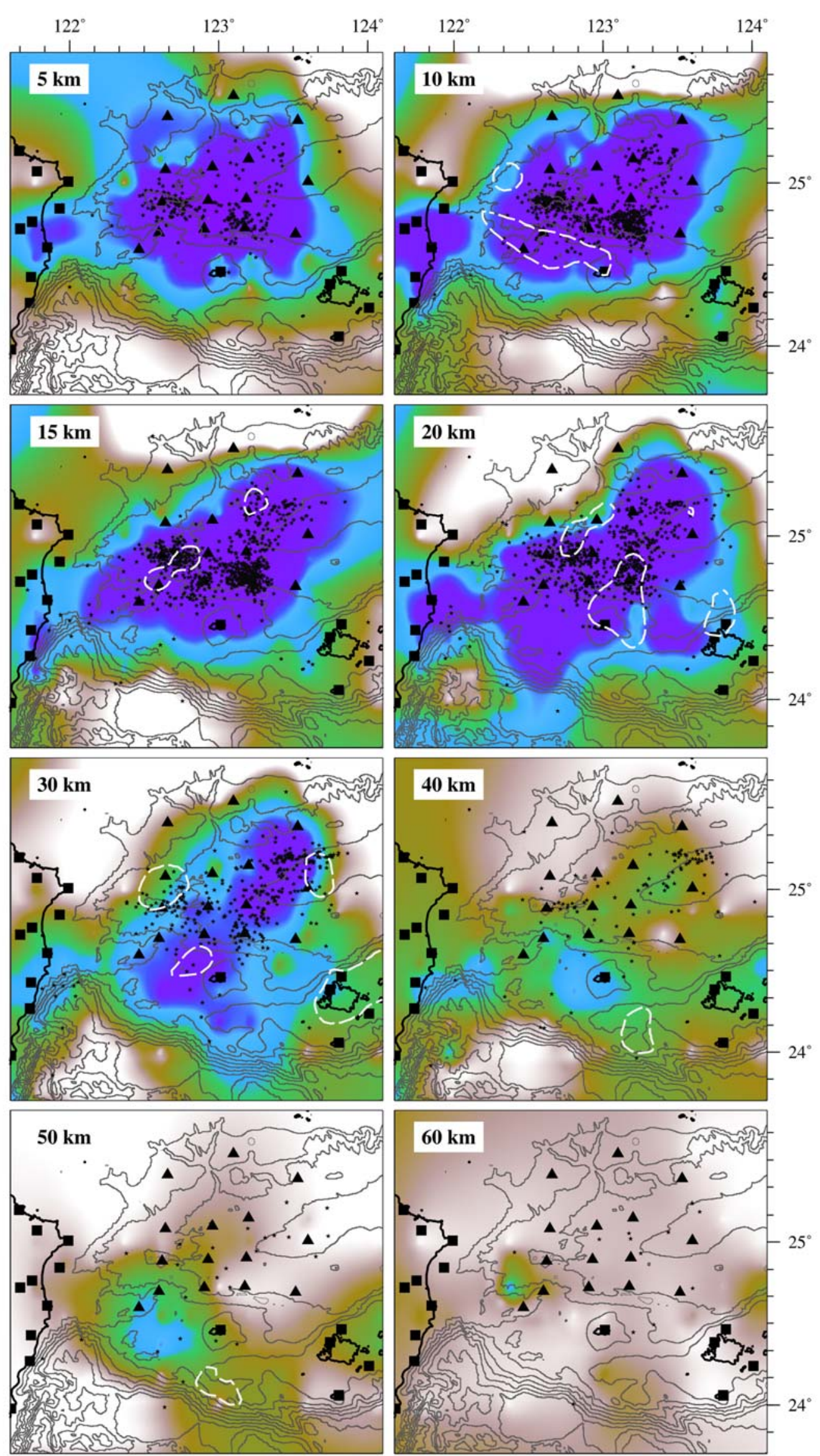

Vp resolution

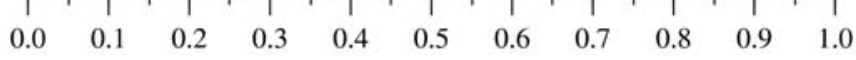

Figure 9 

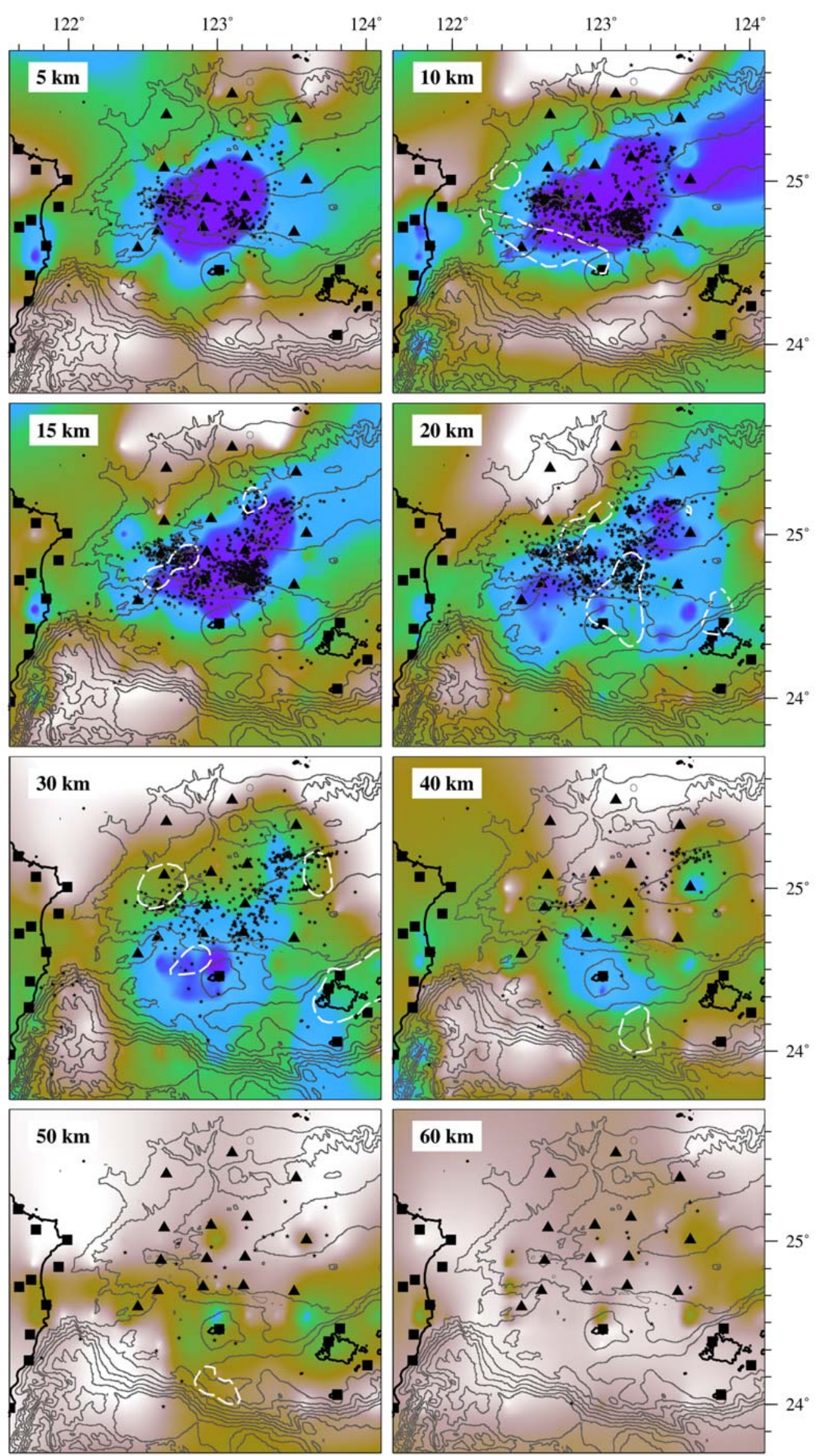

$\mathrm{Vp} / \mathrm{Vs}$ resolution

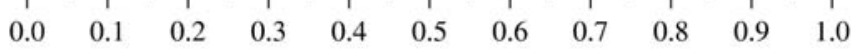

Figure 10 

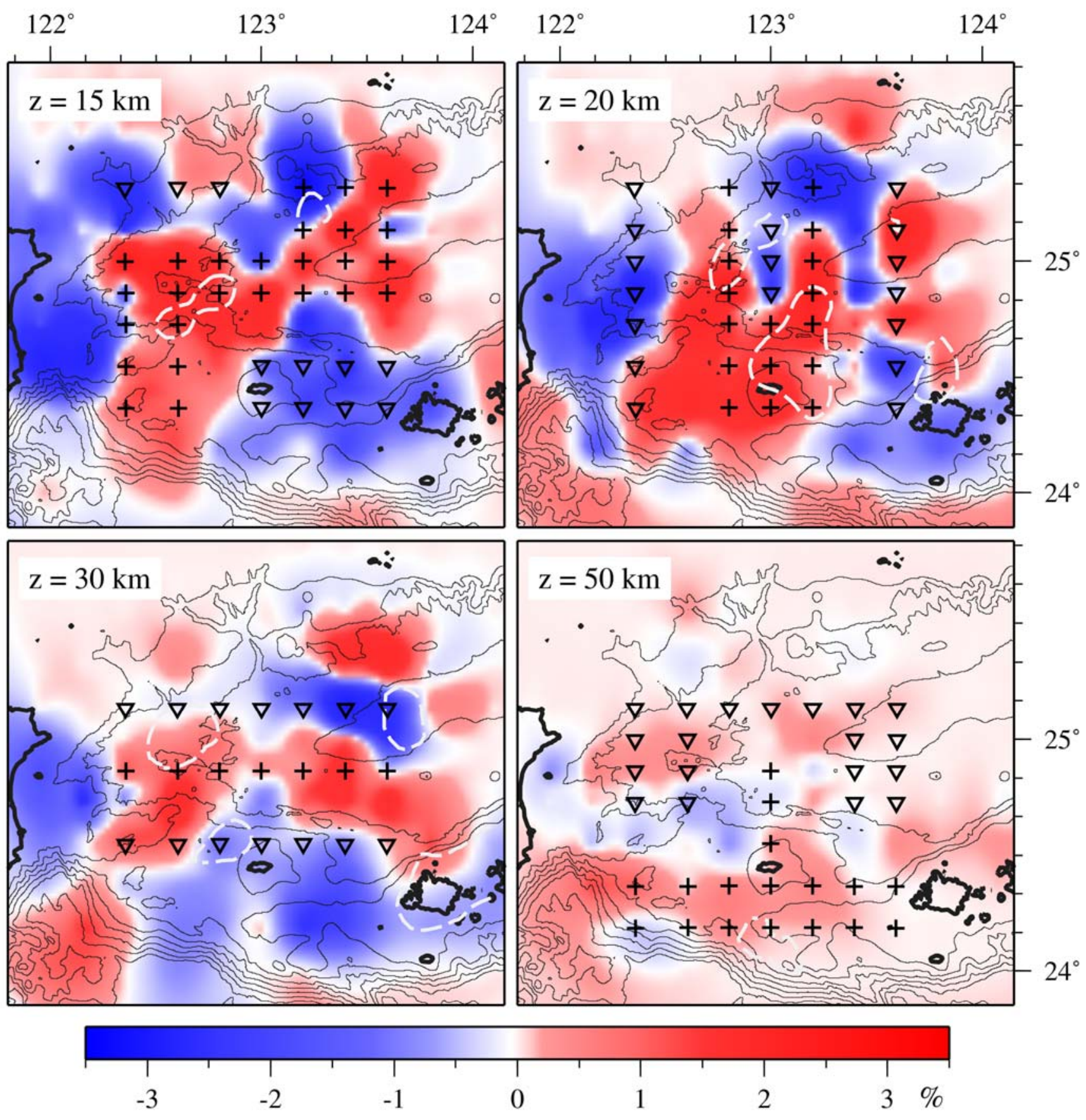

Figure 11 


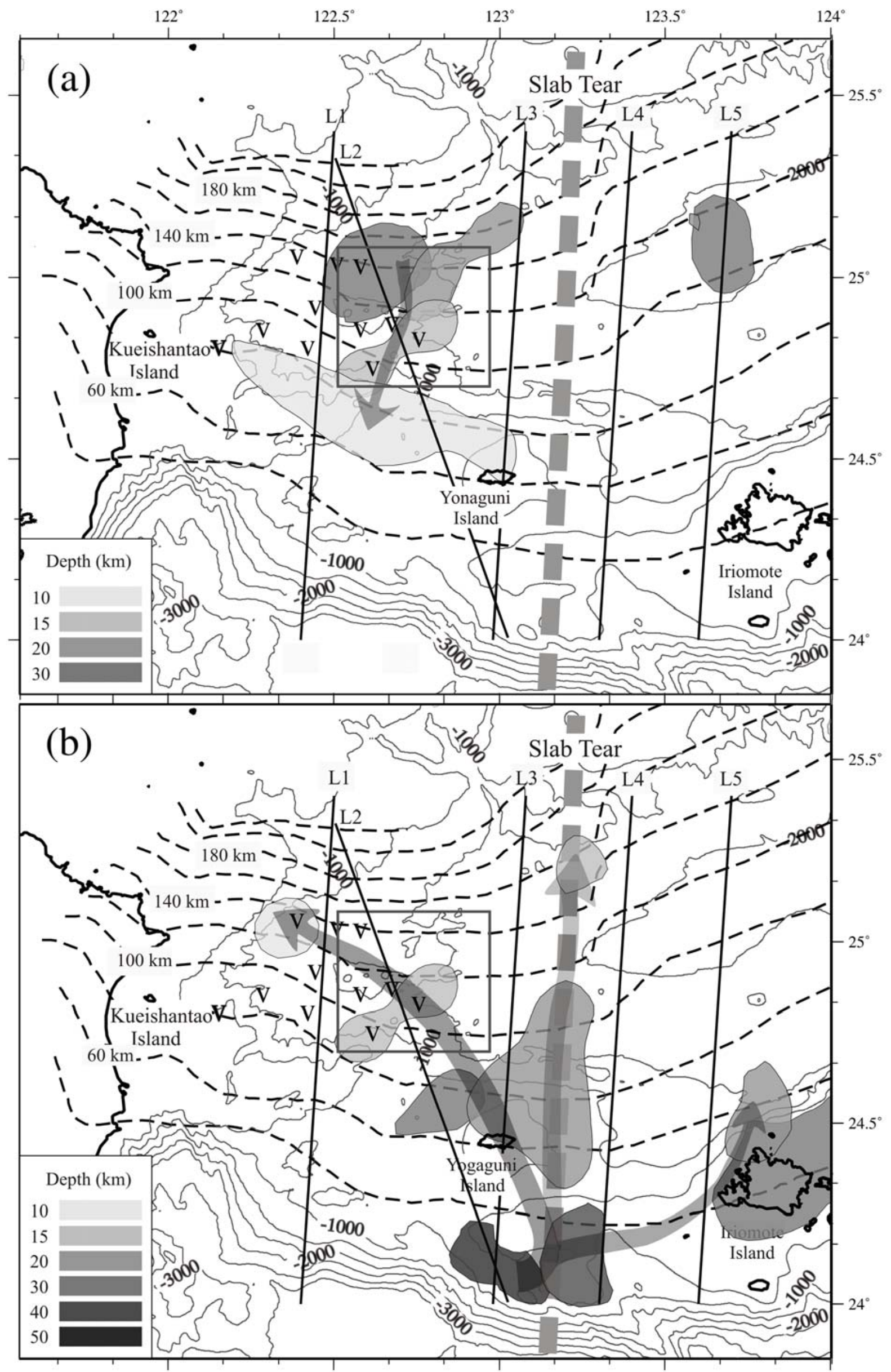

Figure 12 


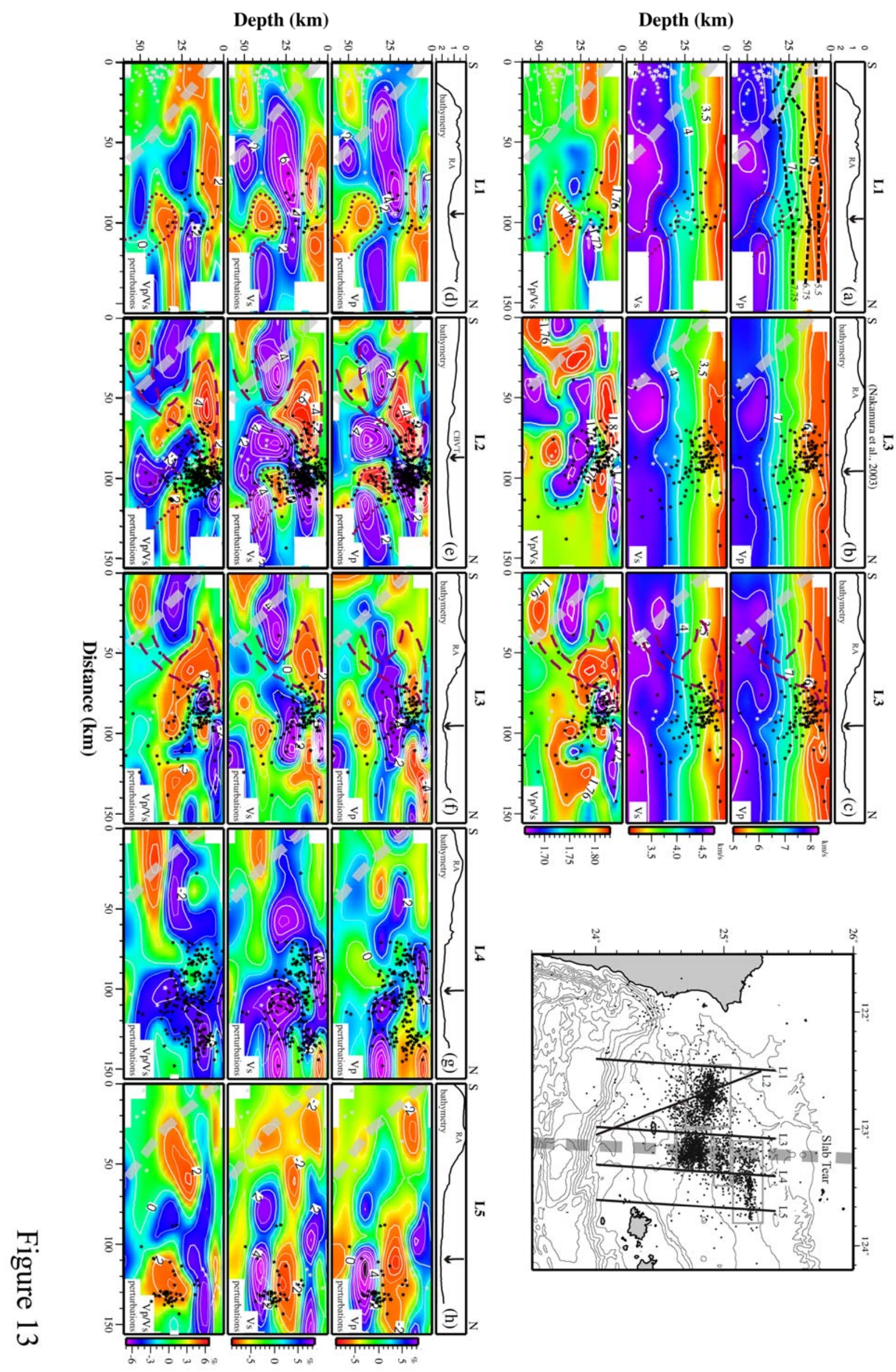




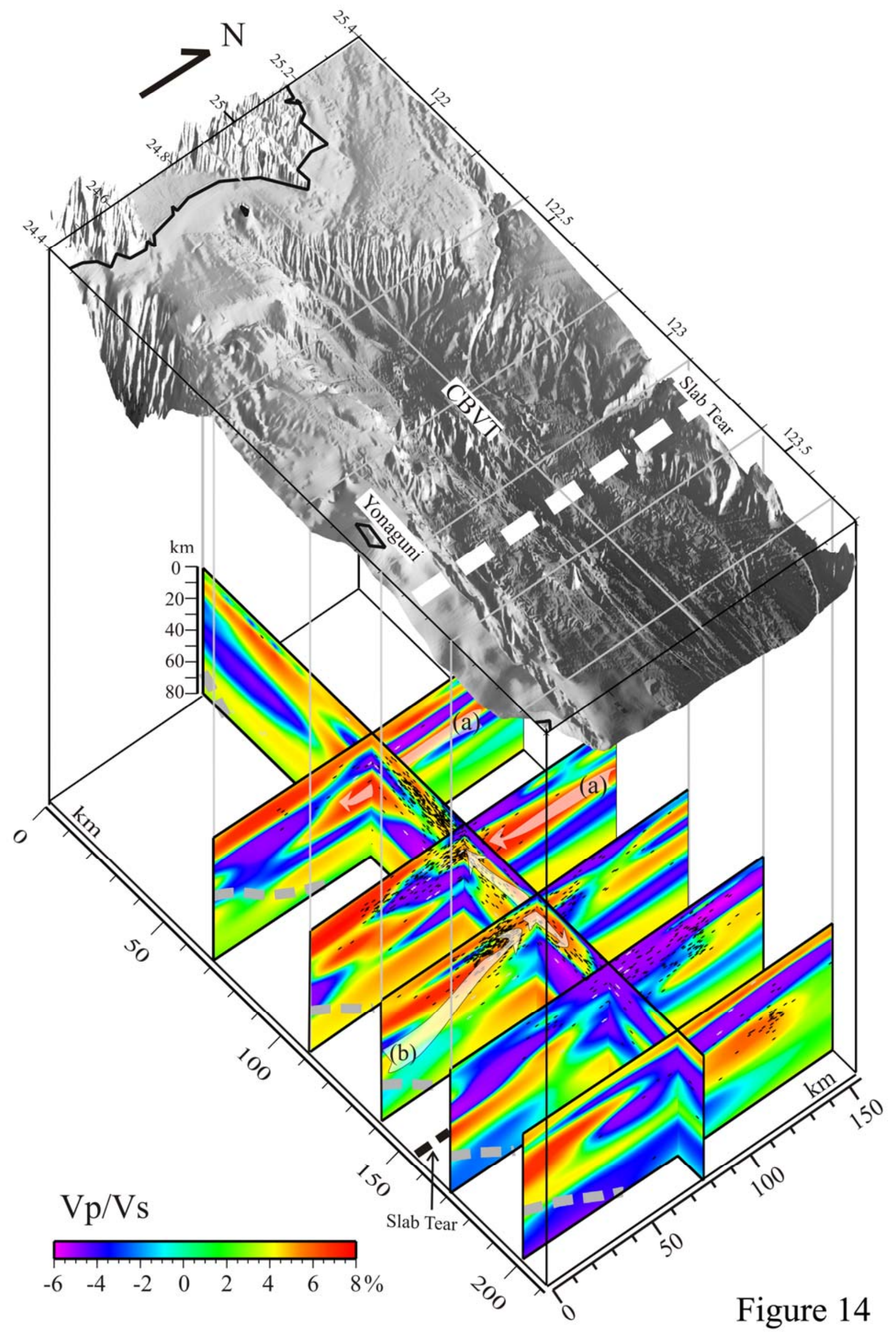




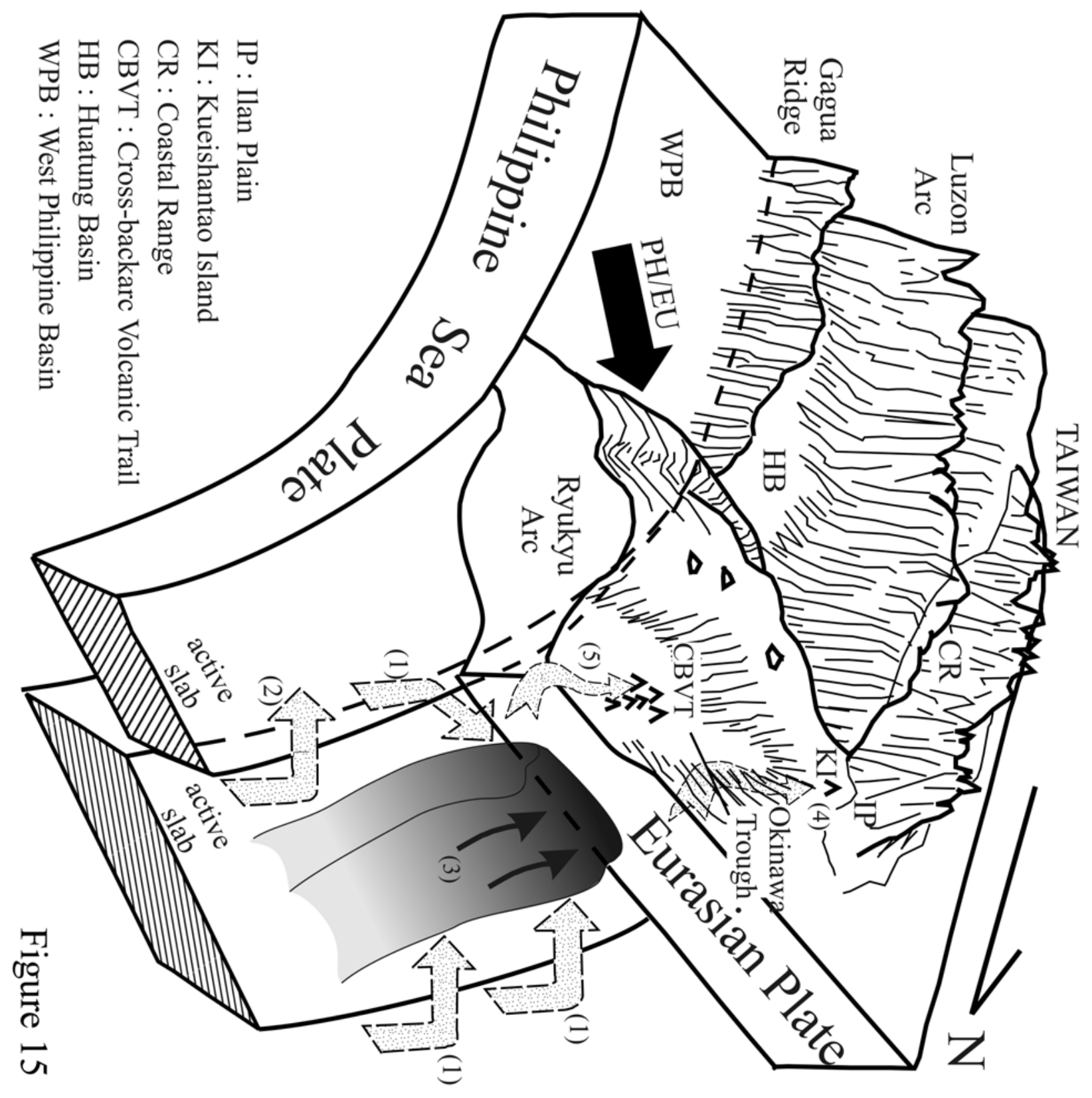

